\title{
Taking Liberties: The Personal Jurisdiction of Military Commissions ${ }^{1}$
}

(August 9, 2008)

\author{
Madeline Morris ${ }^{2}$ \\ with \\ Yaniv Adar, Margarita Clarens, Joshua Haber, \\ Allison Hester-Haddad, David Maxted, James McDonald, \\ George ('Wes') Quinton, Dennis Schmelzer, and Jeffrey Ward
}

\section{Introduction}

On September 11, 2001, Al Qaeda operatives attacked civilian and military targets on US territory, causing thousands of deaths and billions of dollars of economic loss. The next day, the United Nations Security Council unanimously adopted Resolution 1368 characterizing the attack by Al Qaeda as a "threat to international peace and security" and recognizing the right of states to use armed force in self defense. ${ }^{3}$ NATO, for the first time in its history, invoked the obligation of collective self defense under Article 5 of the NATO Treaty. ${ }^{4}$ On September 14, the US Congress passed the Authorization for the Use of Military Force, authorizing the President to use "all necessary and appropriate force against those nations, organizations, or persons he determines planned, authorized, committed, or aided the terrorist attacks. ..."5 Terrorism, conceived until then as crime, was reconceived—as war.

On November 13, 2001, invoking the law of war, President Bush announced that enemy combatants in the US “war on terror” would be subject to trial by military commission—a form of military tribunal last convened in the aftermath of World War II. Issuing a Presidential Military Order (PMO), he stated:

\footnotetext{
1 (c) Madeline Morris 2007.

${ }^{2}$ Professor of Law, Duke Law School.

${ }^{3}$ S.C. Res. 1368, U.N. SCOR, 56th Sess., 4370th mtg., U.N. Doc. S/RES/1368 (Sept. 12 2001).

4 Press Release, North Atlantic Council, Statement by the North Atlantic Council (Sep. 12, 2001), http://www.nato.int/docu/pr/2001/p01-124e.htm.

${ }^{5}$ Pub. L. No. 107-40, 115 Stat. 224 (2001) §§ 1-2.
} 
To protect the United States and its citizens, and for the effective conduct of military operations and prevention of terrorist attacks, it is necessary for individuals subject to this order pursuant to section 2 hereof to be detained, and, when tried, to be tried for violations of the laws of war and other applicable laws by military tribunals. ...

The term "individual subject to this order" shall mean any individual who is not a United States citizen with respect to whom I determine from time to time in writing that:

(1) there is reason to believe that such individual, at the relevant times,

(i) is or was a member of the organization known as al Qaida;

(ii) has engaged in, aided or abetted, or conspired to commit, acts of international terrorism, or acts in preparation therefore, that have caused, threaten to cause, or have as their aim to cause, injury to or adverse effects on the United States, its citizens, national security, foreign policy, or economy; or

(iii) has knowingly harbored one or more individuals described in subparagraphs (i) or (ii) of subsection 2(a)(1) of this order; and

(2) it is in the interest of the United States that such individual be subject to this order. ${ }^{6}$

The military commissions set in place pursuant to that PMO were struck down by the Supreme Court's decision in Hamdan v. Rumsfeld ${ }^{7}$ on June 24, 2006. Three months later, under pressure from the White House, ${ }^{8}$ Congress passed the Military Commissions Act of $2006^{9}$ (MCA) establishing a new set of military commissions, this time with Congressional sanction. The MCA established and governs the military commissions now in operation at the US Naval Station, Guantanamo Bay, Cuba.

The MCA provisions defining the personal jurisdiction of military commissions are not nearly as breezy as the provisions of the PMO that would have allowed military commission

\footnotetext{
${ }^{6}$ President's Military Order of November 13, 2001, Detention, Treatment, and Trial of Certain Non-Citizens in the War Against Terrorism, 66 Fed. Reg. 57,831, 57,833-34 (Nov. 16, 2001).

${ }^{7} 548$ U.S. 557, 126 S.Ct. 2749 (2006).

${ }^{8}$ See Message From The President of The United States Transmitting a Draft of Proposed Legislation Entitled The "Military Commissions Act Of 2006”, H. Doc. No. 109-133, 109th Cong.; 2d Sess., at 6273 (Sept. 7, 2006); Karl Hulse \& Kate Zernike, House Passes Detainee Bill As It Clears Senate Hurdle, N.Y. TiMES, Sept. 28, 2006, p. A20. ("The bill was a compromise worked out between the White House and three Senate Republicans who for weeks had resisted the administration's approach. They contended the White House's initial bill would violate the Constitution and redefine the nation's obligations under the Geneva Conventions, signaling to other nations that they too could rewrite the rules on dealing with combatants seized in wartime.”).

${ }^{9}$ Pub. L. No. 109-366, 120 Stat. 2600 (to be codified at 10 U.S.C. §§ 948a-950w).
} 
jurisdiction over any alien to be determined "from time to time" by the President. The MCA's provisions governing personal jurisdiction, in fact, are exigent, specific, and faithful to the law of war, when properly interpreted. The problem is that they also are remarkably opaque in their wording. At the present writing, a year and a half after passage of the MCA, the regime governing the personal jurisdiction of military commissions is as controversial as it is unclear. ${ }^{10}$

None of the parties to the controversy have called into question the Charming Betsy canon of statutory construction, which requires that, "[a]n act of Congress ought never to be construed to violate the law of nations if any other possible construction remains."11 Indeed, the Court of Military Commissions Review (CMCR), established under the MCA as the military commissions' appellate body, invoked the Charming Betsy doctrine in its first (and, to date, only) opinion construing the MCA.

But, none of the opinions rendered by the military commissions or the CMCR actually has offered a comprehensive analysis of the substantive and procedural requirements for the exercise of personal jurisdiction by military commissions under the international law of war. Without such an articulation of the relevant law, attempts to interpret the MCA's jurisdictional provisions "consistently" with international law have been something of a muddle. The result has been not only significant disarray in the functioning and jurisprudence of the military commissions but, also, damage to the integrity of the law of war- including, particularly, prisoner-of-war (POW) protections.

The present article, in Part II, delineates the law of war governing the personal jurisdiction of military commissions. Part III parses the jurisdictional language of the MCA and argues that, properly construed, the personal jurisdictional framework of the MCA is both

\footnotetext{
${ }^{10}$ See infra Part IV.

${ }^{11}$ Murray v. Schooner Charming Betsy, 6 U.S. (2 Cranch) 64, 118 (1804).
} 
internally coherent and entirely consistent with the law of war. Part IV examines the relevant opinions rendered by the Guantanamo military commissions and the CMCR to date in the light of the law of war and the interpretation of the MCA delineated in Part III. Part V demonstrates that, in each case brought under the MCA to date, military commission jurisdiction has been exercised over a presumptively lawful combatant, in violation of both the MCA and the law of war-with resulting damage to the law of war, the integrity of American governance, and the reputation of the US internationally. Part VI concludes by suggesting a remedy that is as simple as it is critical.

This article does not question the wisdom of applying the law of war to the context of jihadist terrorism — though there is much to question. Rather, the present article assumes arguendo that detained 'combatants' are to be prosecuted before military commissions, pursuant to the MCA, and provides an analysis of what is required if those prosecutions are to be lawful.

\section{Military Commission Jurisdiction under the International Law of War}

The law of war exists to reduce human suffering in armed conflict. Those taken prisoner by the enemy are vulnerable to profound brutality by their captors. The law of war, to the extent it is effective, provides protection for those held in enemy control.

All persons held by enemy forces in armed conflicts are entitled, under the law of war, to a minimal standard of humane treatment. ${ }^{12}$ Only "lawful combatants" held by the enemy, however, are entitled to POW status and its attendant rights and privileges. ${ }^{13}$

\footnotetext{
${ }^{12}$ See Common Article 3, Geneva Conventions of Aug. 12, 1949, 6 U.S.T. 3316, 75 U.N.T.S. 135; Protocol I Additional to the Geneva Conventions of 12 August 1949, and Relating to the Protection of Victims of International Armed Conflicts, art. 75, Dec. 7, 1978, 1125 U.N.T.S. 3 [hereinafter "Protocol I"]. See also U.S. v. Hamdan, supra note 7 at 126 S.Ct. 2749, 2796.

${ }^{13}$ See, Geneva Convention Relative to the Treatment of Prisoners of War, art. 4, Aug. 12, 1949, 6 U.S.T. 3316, 75 U.N.T.S. 135 [hereinafter "POW Convention”].
} 
The criteria for lawful combatant status are delineated in Article 4 of the Geneva

\section{Convention Relative to the Treatment of Prisoners of War (POW Convention). ${ }^{14}$ A combatant}

who falls within those criteria is a lawful combatant. A lawful combatant who falls into the

hands of the enemy is entitled to POW status. Under the law of war, a lawful combatant held by

the enemy is a POW.

${ }^{14}$ Article 4 of the POW Convention states:

A. Prisoners of war, in the sense of the present Convention, are persons belonging to one of the following categories, who have fallen into the power of the enemy:

(1) Members of the armed forces of a Party to the conflict, as well as members of militias or volunteer corps forming part of such armed forces.

(2) Members of other militias and members of other volunteer corps, including those of organized resistance movements, belonging to a Party to the conflict and operating in or outside their own territory, even if this territory is occupied, provided that such militias or volunteer corps, including such organized resistance movements, fulfil the following conditions:

(a) that of being commanded by a person responsible for his subordinates;

(b) that of having a fixed distinctive sign recognizable at a distance;

(c) that of carrying arms openly;

(d) that of conducting their operations in accordance with the laws and customs of war.

(3) Members of regular armed forces who profess allegiance to a government or an authority not recognized by the Detaining Power.

(4) Persons who accompany the armed forces without actually being members thereof, such as civilian members of military aircraft crews, war correspondents, supply contractors, members of labour units or of services responsible for the welfare of the armed forces, provided that they have received authorization, from the armed forces which they accompany, who shall provide them for that purpose with an identity card similar to the annexed model. (5) Members of crews, including masters, pilots and apprentices, of the merchant marine and the crews of civil aircraft of the Parties to the conflict, who do not benefit by more favourable treatment under any other provisions of international law.

(6) Inhabitants of a non-occupied territory, who on the approach of the enemy spontaneously take up arms to resist the invading forces, without having had time to form themselves into regular armed units, provided they carry arms openly and respect the laws and customs of war.

B. The following shall likewise be treated as prisoners of war under the present Convention:

(1) Persons belonging, or having belonged, to the armed forces of the occupied country, if the occupying Power considers it necessary by reason of such allegiance to intern them, even though it has originally liberated them while hostilities were going on outside the territory it occupies, in particular where such persons have made an unsuccessful attempt to rejoin the armed forces to which they belong and which are engaged in combat, or where they fail to comply with a summons made to them with a view to internment.

(2) The persons belonging to one of the categories enumerated in the present Article, who have been received by neutral or non-belligerent Powers on their territory and whom these Powers are required to intern under international law, without prejudice to any more favourable treatment which these Powers may choose to give and with the exception of Articles 8, 10, 15, 30, fifth paragraph, 58-67, 92, 126 and, where diplomatic relations exist between the Parties to the conflict and the neutral or non-belligerent Power concerned, those Articles concerning the Protecting Power. Where such diplomatic relations exist, the Parties to a conflict on whom these persons depend shall be allowed to perform towards them the functions of a Protecting Power as provided in the present Convention, without prejudice to the functions which these Parties normally exercise in conformity with diplomatic and consular usage and treaties.

C. This Article shall in no way affect the status of medical personnel and chaplains as provided for in Article 33 of the present Convention. 
POWs benefit from POW rights only when POW status is acknowledged. The safeguards and procedures governing combatant status determinations under the law of war, therefore, form the linchpin of all POW protections.

The core safeguard for POW rights under the law of war turns on a presumption. A combatant held in the control of the enemy is presumed to be a lawful combatant, entitled to POW protections, unless and until he or she is determined, through a specified legal procedure, to lack POW status. ${ }^{15}$

The one procedure through which the presumption of entitlement to POW rights may be rebutted is a determination by a "competent tribunal" that the person does not come within the criteria for lawful combatant status. Article 5 of the POW Convention, thus, states:

Should any doubt arise as to whether persons, having committed a belligerent act and having fallen into the hands of the enemy, belong to any of the categories enumerated in Article 4 [defining lawful combatants], such persons shall enjoy the protection of the present Convention until such time as their status has been determined by a competent tribunal. ${ }^{16}$

Only when a detained combatant has been determined, by a "competent tribunal," to lack lawful combatant status may that detainee be treated as a non-POW.

The primary goal motivating the promulgation of Article 5, in 1949, was the establishment of a system in which combatant status determinations would be made by a tribunal of several people rather than by an individual decision maker. ${ }^{17}$ As explained in the official Commentary to the POW Convention, the drafters of Article 5 sought to ensure, "that decisions which might have the gravest consequences should not be left to a single person ...."18

\footnotetext{
${ }^{15}$ See POW Convention, supra note 13, art. 5; Protocol I, supra note 12, art. 45(1).

${ }_{17}^{16}$ POW Convention, supra note 13 , art. 5.

${ }^{17}$ See Commentary to the GeneVa Convention Relative to the Treatment of Prisoners of War 77 (HTTP://WWW.ICRC.ORG/IHL.NSF/COM/375-590008?OPENDOCUMENT) (hereinafter, Commentary to the POW Convention).

${ }^{18} I d$.
} 
Article 45(1) of Protocol I Additional to the Geneva Conventions of 1949 (Protocol I)

reiterates the presumption of lawful combatant status applicable to every combatant who falls into the hands of the enemy, and restates that a competent tribunal determination is the sole means for rebutting that presumption that presumption. Article 45(1) provides:

A person who takes part in hostilities and falls into the power of an adverse Party shall be presumed to be a prisoner of war, and therefore shall be protected by the Third Convention, if he claims the status of prisoner of war, or if he appears to be entitled to such status, or if the Party on which he depends claims such status on his behalf by notification to the detaining Power or to the Protecting Power. Should any doubt arise as to whether any such person is entitled to the status of prisoner of war, he shall continue to have such status and, therefore, to be protected by the Third Convention and this Protocol until such time as his status has been determined by a competent tribunal. ${ }^{19}$

The U.S., while not a party to Protocol I, has stated explicitly and repeatedly that Article 45 embodies binding, customary international law of war. ${ }^{20}$

The presumption of lawful combatant status, and the bright-line rule that the presumption may be rebutted only by an article-5 competent tribunal, is explicitly adopted and implemented in regulations binding throughout the US armed forces. Army Regulation 190-8

(AR 190-8) provides:

\section{1-6. Tribunals}

\footnotetext{
${ }^{19}$ Protocol I Additional to the Geneva Conventions of 12 August 1949, and Relating to the Protection of Victims of International Armed Conflicts, art. 45(1), Dec. 7, 1978, 1125 U.N.T.S. 3 [hereinafter "Protocol I”].

The U.S., while not a party to Protocol I, has stated explicitly and repeatedly that the provisions of Article 45 embody binding, customary international law of war, and are adopted and endorsed as such by the United States. See, e.g., Michael Matheson, The US Position on the Relation of Customary International Law to the 1977 Protocols Additional to the 1949 Geneva Conventions, Remarks before Session One of the Humanitarian Law Conference, 2 AM. U. J. INT’L L. \& POL’y 419 (1987) (stating, in his official capacity as Deputy Legal Adviser, US State Department that, "We do support the principle that, should any doubt arise as to whether a person is entitled to [lawful] combatant status, he be so treated until his status has been determined by a competent tribunal.”)

${ }^{20}$ See, e.g., Michael Matheson, The US Position on the Relation of Customary International Law to the 1977 Protocols Additional to the 1949 Geneva Conventions, Remarks before Session One of the Humanitarian Law Conference, 2 AM. U. J. INT’L L. \& POL'Y 419 (1987) (speaking in his official capacity as Deputy Legal Adviser, US State Department).
} 
a. In accordance with Article 5, [POW Convention], if any doubt arises as to whether a person, having committed a belligerent act and been taken into custody by the US Armed Forces, belongs to any of the categories enumerated in Article 4, [POW Convention], such persons shall enjoy the protection of the present Convention until such time as their status has been determined by a competent tribunal.

b. A competent tribunal shall determine the status of any person not appearing to be entitled to prisoner of war status who has committed a belligerent act or has engaged in hostile activities in aid of enemy armed forces, and who asserts that he or she is entitled to treatment as a prisoner of war, or concerning whom any doubt of a like nature exists. ${ }^{21}$

Like the other features of article 5, the requirement that an article 5 tribunal be composed of more than one person is implemented in AR 190-8, which states that a "competent tribunal" shall be "composed of three commissioned officers."22

AR 190-8 was jointly promulgated by the Headquarters of the departments of the Army, Navy, Air Force, and Marine Corps on October 1, 1997. The regulation states explicitly that it, “implements international law, both customary and codified, relating to [enemy prisoners of war]."23

International law, U.S. law and military regulations, and longstanding U.S. policy could not be clearer: A combatant detained by the enemy must be accorded POW rights unless and

\footnotetext{
${ }^{21}$ Army Regulation 190-8, EnEmy Prisoners of WAR, Retained Personnel, Civilian InTERneEs AND Other DETAINEES § § 1-1(b), 1-6 (1 Oct 1997) (hereinafter AR 190-8).

${ }^{22}$ Id. Aside from Army Regulation 190-8, the history of revisions to Army Field Manual 27-19 indicates that the military has consistently required that a "competent tribunal" consist of at least three officers since the term "competent tribunal": was first added to the military lexicon. For example, the Army Field Manual 27-10 dictated that status determinations must be made by a "competent authority" rather than a competent tribunal. Field Manual 27-10, Rules of Land Warfare (Washington: War Department, 1914), 23. The same was true twenty years later. Field Manual 27-10, Rules of Land Warfare (Washington: War Department, 1934), 5. By 1940, however, an extra line of text was added specifying that "[t]he determination ... is to be left to a higher military authority or to military tribunals.” Field Manual 27-10, Rules of Land Warfare (Washington: War Department, 1940), 5. When the manual was revised again following the ratification of the Geneva Conventions, the section was changed to provide that unlawful status be "determined by a competent tribunal" alone. Department of the Army Field Manual 27-10, The Laws of Land Warfare (Washington: Department of the Army, 1956), 19, §71(a). That text, which has remained constant since, further explains that "[a] 'competent tribunal' of the United States for the purpose of determining whether a person ... is or is not entitled to prisoner-of-war status is a board of not less than three officers ....” Id. at 19, §71(c).

${ }^{23} I d$.
} 
until the presumption of lawful combatant status is rebutted through a contrary combatant status determination by an article-5 competent tribunal composed of more than one person.

The rights accorded to POWs include certain rights relating to criminal trials. The POW Convention specifies that "[a] prisoner of war can be validly sentenced only if the sentence has been pronounced by the same courts according to the same procedure as in the case of members of the armed forces of the Detaining Power. ...”24 Because POW rights thus include important protections relating to criminal trials, the recognition or denial of POW status is especially crucial for a detainee who is to stand trial. In light of the heightened significance of POW status in that circumstance, the law of war provides that, if a detainee who has been determined by a competent tribunal to lack POW status is to stand trial for a crime arising from the hostilities, he is entitled to assert POW status and to have the question adjudicated in a de novo combatant status determination, conducted with full judicial process. ${ }^{25}$ The law of war thus requires a twotiered status determination system for cases where a detained combatant who is not held as a POW is to be tried for an offense arising out of the hostilities.

This two-tiered system of combatant status determination is codified in Article 45 of Protocol I Additional to the Geneva Conventions of 1949 (Protocol I). The first paragraph of Article 45, as discussed earlier, reiterates and elaborates upon the core safeguard articulated in Article 5 of the POW Convention-the presumption of lawful combatant status (i.e., POW status, if the individual is held by the enemy), which may be rebutted only by a contrary determination by a competent tribunal.

\footnotetext{
${ }^{24}$ POW Convention, supra note 13, art. 102.

25 See Protocol I, art. 45.
} 
The second paragraph of Article 45 articulates the additional safeguard—-the right to a combatant status adjudication before a judicial tribunal—for a detainee who is "not held as a prisoner of war" and is to be "tried for an offense arising out of the hostilities:"

If a person who has fallen into the power of an adverse Party is not held as a prisoner of war and is to be tried by that Party for an offence arising out of the hostilities, he shall have the right to assert his entitlement to prisoner-of-war status before a judicial tribunal and to have that question adjudicated. Whenever possible under the applicable procedure, this adjudication shall occur before the trial for the offence. ${ }^{26}$

That detainee—whom Article 45(2) specifies is "not held as a prisoner of war"-is, necessarily, either one who does not claim POW status or one who has been determined by $a$ competent tribunal to lack POW status. A detainee who claims POW status, as we have seen, may lawfully be held as a non-POW only if a competent tribunal has found him to be an unlawful combatant ${ }^{27}$ and, therefore, not entitled to POW status. Consequently, the person, referred to in Article 45(2)—who asserts entitlement to POW status, but is "not held as a [POW]"—is, necessarily, a person who has already been found, by a competent tribunal, to lack POW status. A person in that situation, Article 45(2) provides, if he is to be tried for an offense arising out of the hostilities, "shall have the right to assert his entitlement to prisoner-of-war status before a judicial tribunal and to have that question adjudicated.” The Article 45(2) status adjudication, therefore, is necessarily a separate proceeding, conducted subsequent to the competent tribunal determination that initially overcame the presumption of lawful combatant status and thereby permitted the detainee to be "not held as a POW."

\footnotetext{
${ }^{26} I d$., art. 45(2) (emphasis added).

${ }^{27}$ The term "unlawful combatant" does not appear in the Geneva Conventions. It is used here to refer, simply, to a combatant who does not come within the criteria for lawful combatant status. As shall be discussed below, the criteria defining "lawful combatant" status under the MCA are narrower than those of the POW Convention. The difference in criteria is not relevant for immediate purposes, but will be delineated as they become relevant, below.
} 
The US has long endorsed the two-tiered status determination procedure codified in Article 45(2) of Protocol I as a binding feature of the customary international law of war, and has advocated its recognition and enforcement. ${ }^{28}$ Protocol I was negotiated in the wake of the severe mistreatment of US soldiers who were wrongfully denied POW status and summarily convicted as war criminals in North Vietnam. “North Vietnam,” Howard Levie has written, “stated, in effect, that it would regard captured Americans as 'pirates,' people who have destroyed the property and massacred the population of the Democratic Republic of Vietnam, as major war criminals caught in flagrante delicto and liable for judgment in accordance with the laws of the Democratic Republic of Vietnam.”29 In the light of that experience and analogous evasions of POW rights in the Korean war, Article 45(2) was promulgated, with US support and leadership, to strengthen POW protections by entitling a detainee to a public, judicial proceeding to determine combatant status_-de novo-before that person could be tried for war crimes without POW rights at trial. ${ }^{30}$ Ambassador George Aldrich, head of the US delegation in the negotiation of Protocol I, recalls:

[P]aragraph 2 of Article 45 of Protocol I . . . establishes a separate right of any person who has fallen into the power of an adverse party that intends to try him for an offense arising out of the hostilities to have his entitlement to POW status determined by a judicial tribunal. When that text was negotiated, the United States government was painfully aware of the experiences in Korea and Vietnam, where many American military personnel were mistreated by their captors and denied POW status by mere allegations that they were all criminals. ${ }^{31} 32$

\footnotetext{
${ }^{28}$ See infra, pp. 9-12.

${ }^{29}$ Howard S. Levie, The US Position on the Relation of Customary International Law to the 1977 Protocols Additional to the 1949 Geneva Conventions, Remarks before Session One of the Humanitarian Law Conference, 2 AM. U. J. INT’L L. \& POL’Y 533, 535 (1987).

${ }^{30}$ See George H. Aldrich, Editorial Comments: The Taliban, Al Qaeda, and the Determination of Illegal Combatants, 96 AM. J. INT’L L. 891, 898 (2002)

${ }^{31}$ George H. Aldrich, Comments on the Geneva Protocols, 320 InT'L REV. RED Cross 508-10 (1997), available at http://www.icrc.org/Web/eng/siteeng0.nsf/html/57JNV2.

${ }^{32}$ Aldrich, supra note 25, at 898 [internal citations omitted].
} 
Because the US opposed some of the provisions of Protocol I as it was ultimately adopted, the US did not become a party to the treaty. Yet there were certain provisions that the US not only supported, but viewed as crucially important. The US, therefore, in 1987, identified and endorsed specific provisions of Protocol I as customary international law, and urged other states also to recognize those provisions as binding. ${ }^{33}$

Article 45 of Protocol I featured prominently among the provisions that the United States so endorsed. Delineating the US position on Protocol I, Michael Matheson, then-Deputy State Department Legal Adviser, unequivocally articulated the United States' endorsement of: the presumption of entitlement to POW rights for all combatants held by the enemy; the requirement that the presumption remain in force unless a contrary status determination is made by a competent tribunal; and, the right to a judicial adjudication of combatant status where an individual held as a non-POW is to be tried for crimes arising from the hostilities. ${ }^{34}$ As he stated:

We do support the principle that, should any doubt arise as to whether a person is entitled to [lawful] combatant status, he be so treated until his status has been determined by a competent tribunal, as well as the principle that if a person who has fallen into the power of an adversary is not held as a prisoner or war and is to be tried for an offense arising out of the hostilities, he should have the right to assert his entitlement to prisoner-of-war status before a judicial tribunal and to have that question adjudicated. Those principles are found in Article 45. ${ }^{35}$

\footnotetext{
${ }^{33}$ See Michael Matheson, The US Position on the Relation of Customary International Law to the 1977 Protocols Additional to the 1949 Geneva Conventions, Remarks before Session One of the Humanitarian Law Conference, 2 AM. U. J. INT'L L. \& POL’Y 419 (1987).

${ }^{34}$ Id. at $419-26$.

${ }^{35}$ Id. at 425-26. The Government suggested in its Reply to Amicus Curiae Brief in United States v. Khadr that, rather than endorsing Article 45 as customary international law, Mr. Matheson in fact "affirmatively disclaimed the 'customary' legal effect of Article 45." Prosecution Reply to Amicus Curiae at 4, United States v. Khadr, CMCR 07-001, 24 n. 38 (2007). The Government quotes Mr. Matheson as saying:

[W] support the principle that persons entitled to combatant status be treated as [POWs] in accordance with the [POW Convention], as well as the principle that combatant personnel distinguish themselves from the civilian populations while engaged in military operations. Those statements are, of course, related to but different from the content of Article[] 45 . . . Id. at 26.
} 
State Department Legal Adviser Abraham Sofaer elaborated: "We therefore intend to

consult with our allies to develop appropriate methods for incorporating these provisions ...

into rules that govern our military operations . ..."36 The US has, indeed, incorporated the

provisions of Article 45 into its regulations and operational guidelines ${ }^{37}$ and has identified those

The Government's position on this point arises from confusion caused by an error (probably, typographical) in the text of Matheson's remarks as published. Looking at the full quotation-without the ellipses - provides some clarity. Picking up where the Government's quotation leaves off, the statement reads as follows.

... [R]elated to but different from the content of articles 44 and 45, which relax the requirements of the Fourth Geneva Convention concerning prisoner-of-war treatment for irregulars, and, in particular, include a special dispensation allowing individuals who are said to be unable to observe this rule in some circumstances to retain combatant status, if they carry their arms openly during engagements and deployments preceding the launching of attacks. . .

On the other hand, we do support the principle that, should any doubt arise as to whether a person is entitled to combatant status, he be so treated until his status been determined by a competent tribunal, as well as the principle that if a person who has fallen into the power of an adversary is not held as a [POW] and is to be tried for an offense arising out of the hostilities, he should have a right to assert his entitlement to [POW] status before a judicial tribunal and to have that question adjudicated. Those principles are found in article 45. Id., at 425-26 (emphasis added).

Those two paragraphs of Matheson's statement, as reproduced in the published text, are contradictory. The first says that the US rejects the provisions of Article 45, and the second says that the US supports the provisions of Article 45. The contradiction was caused by the erroneous inclusion of the words "and 45 " in the first paragraph of the quotation. That this was in error becomes clear upon a cursory reading of Article 45. Article 45 contains nothing that "relax[es] the requirements ... concerning prisoner-of-war treatment for irregulars" or that "allow[s] individuals who are said to be unable to ... distinguish themselves from the civilian populations in some circumstances to retain combatant status." Article 45, in fact, contains nothing relating to the requirements for prisoner-of-war status. ${ }^{35}$ In other words, the reference to Article 45 in the first paragraph quoted just makes no sense. By contrast, Article 44, which is also cited in the first paragraph of the quote, consists of eight paragraphs defining the requirements for prison-of-war status, including several that relax the requirements concerning prisoner-of-war treatment for irregulars. Subsection 3 of Article 44, in particular, states: "[W]here ... an armed combatant cannot so distinguish himself [from the civilian population], he shall retain his status as a combatant. ..." The logical conclusion is that only Article 44, and not Article 45, was supposed to be included in the first paragraph.

This conclusion is borne out by another aspect of the first paragraph of the Matheson quotation. Matheson states that "the executive branch regards this provision as highly undesirable ...." Matheson apparently intended to refer to one article ("this provision"), not two, in the first paragraph.

The authors confirmed this point, by telephone, with the State Department officials directly involved at that time. They confirmed that the reference to Article 45 in the first paragraph of the quotation was unintended.

${ }^{36}$ Abraham Sofaer, The US Position on the Relation of Customary International Law to the 1977 Protocols Additional to the 1949 Geneva Conventions, 2 AM. U. J. INT’L L. \& POL’y 419, 471 (1987).

${ }^{37}$ See, e.g., AR 190-8, supra, note 20; DEPARTMENT OF THE NAVY, NWP 1-14M: THE COMMANDER's HANDBOOK ON THE LAW OF NAVAL OPERATIONS 11-3 (1995), available at http://lawofwar.org/naval_warfare_publication_N114M.htm, ("Should a question arise regarding a captive’s entitlement to prisoner of war status, that individual should be accorded prisoner-of-war treatment until a competent tribunal convened by the captor determines the status to which that person is properly entitled. Individuals captured ... as illegal combatants have the right to assert their claim of entitlement to prisoner-of-war status before a judicial tribunal and to have that question adjudicated.”) 
provisions as reflecting customary international law. ${ }^{38}$ Most recently, the Court of Military Commissions Review cited the rights embodied in Article 45 as a part of the customary international law of war. ${ }^{39}$

In sum, under the international law of war-endorsed and adopted as such by the US—all combatants held by enemy forces are presumed to be lawful combatants, entitled to POW rights and protections, from the time they are taken into captivity. That presumption may be rebutted only through a determination of unlawful combatant status by a competent tribunal composed of more than one person. A combatant who (pursuant to a competent tribunal determination) is held as a non-POW, and who is to be tried for crimes arising from the hostilities has the right to assert POW status and to have a de novo judicial adjudication of combatant status, separate and distinct from the status determination earlier made by a competent tribunal. That status adjudication provides an added layer of protection against the wrongful deprivation of POW trial rights to a combatant who, in facing criminal prosecution by the enemy, is in a singularly vulnerable position.

\section{Personal Jurisdiction under the MCA}

The personal jurisdictional framework of the Military Commissions Act of 2006 is not drafted as clearly as might have been hoped; and this has caused difficulty for the courts that have sought to apply it. Nevertheless, when the MCA is read alongside the law of war, the jurisdictional structure of the Act becomes transparent and is revealed to be fully consistent with the requirements of the law of war, described in Part II, above.

The MCA provides that the military commissions established under the Act shall have jurisdiction only over unlawful combatants. ${ }^{40}$ In accordance with the law of war, the MCA

\footnotetext{
${ }^{38}$ See, e.g., JUdGe AdVOCATE GENERAL's SCHOOL, U.S. ARMy, OPERATIONAL LAW HANDBOOK, JA 422 at $18-2$ (1997); Judge Advocate General’s School, U.S. Army, Operational LAw HandBoOK, Ch. 2 (2002).

${ }^{39}$ United States v. Khadr, CMCR 07-001, 24 n. 38 (2007).
} 
provides that lawful enemy combatants held by the US may be prosecuted only before the same courts—courts-martial—as US service members would be. ${ }^{41}$ The MCA could not be clearer on this point. The stated purpose of the MCA is to establish, "procedures governing the use of military commissions to try alien unlawful enemy combatants. ....42 The Act provides: “A military commission under this chapter shall have jurisdiction to try any offense made punishable by this chapter or the law of war when committed by an alien unlawful enemy combatant. ..."43 In an abundance of caution, the Act further states that, "military commissions under this chapter shall not have jurisdiction over lawful enemy combatants. Lawful enemy combatants who violate the law of war are subject to [courts-martial]."44

The MCA, properly interpreted, requires a determination of unlawful combatant status by a competent tribunal as a prerequisite to the attachment of military commission jurisdiction, as is required under the law of war. ${ }^{45}$ The text and structure of the MCA support this interpretation.

MCA § 948(d), entitled “Jurisdiction,” is composed of four points:

\section{“§ 948d. Jurisdiction of military commissions}

“(a) JURISDICTION.-A military commission under this chapter shall have jurisdiction to try any offense made punishable by this chapter or the law of war when committed by an alien unlawful enemy combatant before, on, or after September 11, 2001.

“(b) LAWFUL ENEMY COMBATANTS.-Military commissions under this chapter shall not have jurisdiction over lawful enemy combatants. Lawful enemy combatants who violate the law of war are subject to chapter 47 of this title. Courts-martial established under that chapter shall have jurisdiction to try a lawful enemy combatant for any offense made punishable under this chapter. “(c) DETERMINATION OF UNLAWFUL ENEMY COMBATANT STATUS DISPOSITIVE.-A finding, whether before, on, or after the date of the enactment of the Military Commissions Act of 2006, by a Combatant

\footnotetext{
${ }^{40} 10$ U.S.C. $\S 948 d(a)$.

${ }^{41}$ See supra text accompanying note 24 .

${ }^{42} I d$. § 948b(a).

${ }^{43} I d$. § 948d(a).

${ }^{44}$ Id. § 948d(b).

${ }^{45}$ See infra remainder of Part III.
} 
Status Review Tribunal or another competent tribunal established under the authority of the President or the Secretary of Defense that a person is an unlawful enemy combatant is dispositive for purposes of jurisdiction for trial by military commission under this chapter.

“(d) PUNISHMENTS.-A military commission under this chapter may, under such limitations as the Secretary of Defense may prescribe, adjudge any punishment not forbidden by this chapter, including the penalty of death when authorized under this chapter or the law of war.

The "Jurisdiction" provision, thus: delineates the subject-matter and personal jurisdiction of military commissions (the latter extending only to "alien unlawful enemy combatants"); indicates that lawful combatants are to be tried by courts-martial; provides that competent tribunal determinations of combatant status are “dispositive” for purposes of jurisdiction for trial by military commission; ${ }^{46}$ and, defines the punitive jurisdiction of commissions.

The "Jurisdiction" section indicates that lawful combatants are to be sent for trial in one forum (courts-martial), and unlawful combatants in another (military commissions). The definitions of "lawful combatant” and "unlawful combatant” are provided in a separate section of the Act, entitled "Definitions." The categorization of enemy combatants into two classessubject to trial in two distinct forums_-necessitates a mechanism for determining, in each given case, the forum to which that prosecution should be sent. A mechanism is required to direct the initial assignment of the case to one jurisdiction or the other. The MCA specifies that the competent tribunal is the mechanism for making the initial status determination necessary to assign each case to a forum. The MCA is not nearly as clear as it might have been on this crucial matter. Nevertheless, the information is there and, when the Act is read alongside the law of war, its meaning is absolutely clear. The initial determination for distinguishing between cases

\footnotetext{
${ }^{46}$ See discussion, infra pp. 20-23.
} 
to be referred to military commission and those to be referred to courts-martial must be made by a “Combatant Status Review Tribunal or other competent tribunal.,"47

This point needs to be examined in detail. The MCA states: “a finding . . . by a . . . competent tribunal ... that a person is an unlawful enemy combatant is dispositive for purposes of jurisdiction for trial by military commission.” That the competent tribunal finding is termed “dispositive” language might seem to suggest that, where there has been a prior (“dispositive”) competent tribunal determination, a military commission is precluded from adjudicating combatant status to determine its own jurisdiction. In fact, the contrary is true. The competent tribunal determination is, in the words of the MCA, “dispositive for purposes of jurisdiction for trial by military commission.” Once that "jurisdiction for trial” is established by the competent tribunal determination, then, in the course of that trial, the military commission may, like any court, exercise jurisdiction to determine its own jurisdiction-including the de novo adjudication of combatant status where appropriate. That de novo adjudication of status is consistent with the MCA, as is demonstrated below, and is required by the provisions of article 45(2), as shall be shown as well. To see the full picture-and to understand how a "dispositive" competent tribunal determination is consistent with a subsequent, de novo, adjudication of status by a military commission, requires examining not only the MCA's “Jurisdiction” section, but also its section on "Definitions."

In a location remote from the section entitled "Jurisdiction," the MCA articulates two definitions of the term "unlawful combatant":

\section{“§ 948a. Definitions}

"In this chapter:

\footnotetext{
${ }^{47} 10$ U.S.C. $\S 948 d(c)$.

The distinction between Combatant Status Review Tribunals (CSRTs) and other competent tribunals is not relevant for immediate purposes, but will be discussed in Part IV, infra.
} 
“(1) UNLAWFUL ENEMY COMBATANT.-(A) The term 'unlawful enemy combatant' means-

"(i) a person who has engaged in hostilities or who has purposefully and materially supported hostilities against the United States or its cobelligerents who is not a lawful enemy combatant (including a person who is part of the Taliban, al Qaeda, or associated forces);

or

"'(ii) a person who, before, on, or after the date of the enactment of the Military Commissions Act of 2006, has been determined to be an unlawful enemy combatant by a Combatant Status Review Tribunal or another competent tribunal established under the authority of the President or the Secretary of Defense. ${ }^{48}$

The two definitions are posed disjunctively—one or the other may apply. But, determination of combatant status by a competent tribunal is a mechanism for determining combatant status. Why, then, does the Act list a competent-tribunal determination of unlawful combatancy as a definition of unlawful combatant status? And what is the purpose of the othersubstantive—definition of “unlawful combatant?” When the requirement of §948d(b) on "Jurisdiction"— that "military commissions shall not have jurisdiction over lawful enemy combatants"—-is read in conjunction with §948a on "Definitions," ${ }^{49}$ the personal jurisdictional framework of the MCA becomes clear.

The two definitions of "unlawful combatant" have distinct functions, relevant at different stages of the proceedings. The substantive definition of "unlawful combatant" (definition (i)) ${ }^{50}$ is to be applied by any entity—competent tribunal, military commission, or appellate court— evaluating a detainee's combatant status. Definition (ii)—that an "unlawful combatant" is a

\footnotetext{
${ }^{48}$ Id. § 948(a)(1) (emphasis added). The "Combatant Status Review Tribunals [CSRTs]," referred to in §948a(1)(A)(ii) were established in 2004 by order of the U.S. Deputy Secretary of Defense. See Paul Wolfowitz, Order Establishing Combatant Status Review Tribunal (July 7, 2004), available at http://www.defenselink.mil/news/Jul2004/d20040707review.pdf. In accordance with the terms of that order and with the regulations promulgated thereunder, a CSRT determines whether a detainee is an enemy combatant, but not whether he is a lawful or an unlawful enemy combatant. See id.

The CMCR has ruled that, because the MCA limits military commission jurisdiction to unlawful enemy combatants, a CSRT determination of enemy combatancy cannot form the basis for military commission jurisdiction under the MCA. See United States v. Khadr, CMCR Case No. 07-001 (Sep. 24, 2007).

${ }^{49}$ Id. §948d(b).

${ }^{50}$ Id. § 948a(1)(A)(i).
} 
person who has been so designated by a competent tribunal—is to be applied in making the initial determination of the forum (court-martial or military commission) to which a given case should be directed. The determination of unlawful combatant status by a competent tribunal is the necessary and sufficient condition for the initial submission of a case to military-commission jurisdiction. ${ }^{51}$ If that status determination has been made, the detainee may be treated as an unlawful combatant and, therefore, military commission jurisdiction may attach. It is in this sense that the competent-tribunal determination "defines" "unlawful combatant" for this stage of the proceedings.

The competent-tribunal determination of unlawful combatant status is a necessary prerequisite to any exercise of military commission jurisdiction. Only once a determination of unlawful combatant status has been made by a competent tribunal and the presumptive right to POW treatment has, thereby, been rebutted, may military commission jurisdiction attach in the first instance.

Other courts, by contrast, routinely exercise jurisdiction to determine their own jurisdiction as an initial matter — even while recognizing that the jurisdictional inquiry may result in a determination that the court has (and, in some sense, $h a d$ ) no jurisdiction over the case. ${ }^{52}$ Military commissions are unlike other courts in this respect because of the presumption of lawful combatant status, which excludes potential defendants from military commission jurisdiction unless and until that presumption is lawfully rebutted by a competent tribunal. MCA §948d(b) states that, "Military commissions under this chapter shall not have jurisdiction over lawful enemy combatants." 53 Rather, it provides, lawful combatants, like members of the US armed

\footnotetext{
${ }^{51} I d . \S 948 \mathrm{a}(1)(\mathrm{A})(\mathrm{ii})$.

${ }^{52}$ See infra note 45 and accompanying text.

5310 U.S.C. § 948d(b) (emphasis added).
} 
forces, shall be subject to court-martial jurisdiction. ${ }^{54}$ In so providing, the MCA implements article 102 of the POW Convention, which provides that persons protected by the Convention may be prosecuted only, "by the same courts according to the same procedure as in the case of members of the armed forces of the Detaining Power." ${ }^{\text {55 }}$

The exclusion from military commission jurisdiction, enunciated in MCA § 948d(b) and required by POW Convention article 102, applies, like all POW rights, to any detainee from the time he is detained and remains in force unless and until a determination rebutting the presumption of POW status is made by an article-5 competent tribunal. The law is utterly clear that all detained combatants shall receive the full protection of the POW Convention "from the time they fall into the power of the enemy" ${ }^{\text {"56 }}$ Article 5 of the Convention states,

The present Convention shall apply to the persons referred to in Article 4 [defining lawful combatants] from the time they fall into the power of the enemy and until their final release and repatriation.

Should any doubt arise as to whether persons, having committed a belligerent act and having fallen into the hands of the enemy, belong to any of the categories enumerated in Article 4, such persons shall enjoy the protection of the present Convention until such time as their status has been determined by a competent tribunal.

The operation of the MCA's exclusion of lawful combatants from military commission jurisdiction (as required by the law of war)—-together with the black-letter law requiring that POW rights be honored by the detaining state from the beginning of captivity until a contrary determination is rendered by an article-5, competent tribunal determines otherwise-places the military commission in a decidedly different position than other courts relative to the initial determination of jurisdiction: A detainee, prior to a competent-tribunal determination of unlawful combatant status is a presumptively lawful combatant, entitled to treatment in

\footnotetext{
${ }^{54}$ See id.

${ }^{55}$ POW Convention, art. 102 (emphasis added).

${ }^{56}$ POW Convention, art. 5 (emphasis added).
} 
accordance with MCA § 948d(b) and the POW right (article 102) that it implements. The rebuttal of presumptive lawful combatant status by a competent tribunal is, thus, a necessary condition for the attachment of military commission jurisdiction.

The competent-tribunal determination of unlawful combatant status is also a sufficient condition for the initial submission of a case to military commission jurisdiction. That is the meaning of the provision, in $\S$ 948d(c) on "Jurisdiction,” that, “[a] finding . . . by a ... competent tribunal ... that a person is an unlawful enemy combatant is dispositive for purposes of jurisdiction for trial by military commission. ${ }^{, 57}$ The competent-tribunal finding is "dispositive" in that it is a sufficient condition for the initial submission of a case to militarycommission jurisdiction; nothing additional is required to rebut the detainee's presumptive POW status and thereby to establish the initial jurisdiction of a military commission. That jurisdiction may be exercised notwithstanding any pending appeal of the competent tribunal's determination.

As stated in the Rules for Military Commissions (RMC):

A finding ... by a ... competent tribunal ... that a person is an unlawful enemy combatant is dispositive for purposes of jurisdiction for trial by a military commission under the M.C.A. The determination by the tribunal shall apply for purposes of military commission jurisdiction without regard to any pending petitions for review or other appeals. ${ }^{58}$

It makes perfect sense that Congress provided in the MCA that a competent tribunal determination is "dispositive for purposes of jurisdiction for trial by military commission."59 The MCA provides, in a separate section, for federal appellate review of certain combatant status determinations by competent tribunals. ${ }^{60}$ To ensure that appellate review of competent tribunal

\footnotetext{
${ }^{57} 10$ U.S.C. $\S 948 d(c)$ (emphasis added).

${ }^{58}$ Manual for Military Commissions, Part II, Rules for Military Commission [hereinafter RMC], Rule 202(b) (2007).

${ }^{59} 10$ U.S.C. $\S 948 d(c)(2006)$.

${ }^{60}$ Section 7(a) of the MCA incorporates section 1005(e)(2)(A) of the Detainee Treatment Act of 2005 (DTA), which provides that: "[T]he United States Court of Appeals for the District of Columbia Circuit shall have exclusive jurisdiction to determine the validity of any final decision of a Combatant Status Review Tribunal that an alien is
} 
determinations would not delay military commission proceedings, Congress specified that the competent tribunal determination shall be dispositive "for purposes of jurisdiction for trial by military commission.,"61

The "dispositive" clause does not mean that, at that trial, the military commission is prohibited from making a combatant status determination to ascertain its own jurisdiction or to rule on a challenge to personal jurisdiction. It means, rather, that a competent tribunal's determination of unlawful combatant status may form the basis for the initial exercise of military commission jurisdiction notwithstanding any pending appeal of the competent tribunal's determination.

Congress had to identify, in the MCA, the mechanism for making the initial status determination that would determine whether a given case would be allocated to a military commission or to a court-martial. Once "jurisdiction for trial by military commission" is established as an initial matter through the competent-tribunal determination, the military commission may then exercise jurisdiction—in the course of that trial— to review its own jurisdiction. But first the military commission has to have the case. That is why the "dispositive clause" reads, "is dispositive for purposes of jurisdiction for trial by military commission" rather than, "is dispositive of military commission jurisdiction."

The competent tribunal determination is not—and could not be—dispositive of military commission jurisdiction in the sense that it would divest the military commission of jurisdiction to determine combatant status in order to ascertain its own jurisdiction. The jurisdiction to determine its own jurisdiction has long been recognized as fundamental among the necessary and

properly detained as an enemy combatant.” Detainee Treatment Act of 2005, Pub. L. No. 109-148, Div. A, tit. 10, 119 Stat. 2739, §1005(e)(2)(A) (2005).

${ }^{61} 10$ U.S.C. § $948 d(\mathrm{c})(2006)$. 
inherent powers of a court. ${ }^{62}$ Indeed, the Rules for Military Commissions make the point succinctly, stating: "A military commission always has jurisdiction to determine whether it has jurisdiction., ${ }^{63}$

Once the presumption of lawful combatant status has been rebutted by a competent tribunal and military commission jurisdiction has lawfully attached, then—consistent with the Article 45(2) right to an adjudication of combatant status for a person who is not held as a POW and is to be tried for an offense arising from the hostilities—-the military commission may adjudicate combatant status to determine its own jurisdiction. When the commission conducts that combatant status adjudication, the substantive definition of "unlawful combatant" (definition (i)) is to be applied.

In sum, when and only when the presumption of POW status has been lawfully rebutted by a competent tribunal may initial military commission jurisdiction attach. The military commission may then, as part of its functions in conducting criminal proceedings, hear motions challenging its personal jurisdiction, including challenges based on the assertion of POW status. ${ }^{65}$ In ruling on such motions (or on its own motion), the commission may make a combatant status determination in order to determine its own jurisdiction. ${ }^{66}$ The MCA's

\footnotetext{
${ }^{62}$ See United States v. Mine Workers, 330 U.S. 258, 291 (1947); Cargill Ferrous Intern. v. SEA PHOENIX MV, 325 F.3d 695, 704 (5th Cir. 2003) ("A bedrock principle of federal courts is that they have jurisdiction to determine jurisdiction.”); Nestor v. Hershey, 425 F.2d 504 (D.C. Cir. 1969) (“[W]e always have jurisdiction to determine our jurisdiction”); United States v. Harmon, 63 M.J. 98, 101 (C.A.A.F. 2006); United States v. Melanson, 53 M.J. 1, 2 (C.A.A.F. 2000). See also Government's Brief on Behalf of Appellant at 20, in United States v. Khadr, C.M.C.R. 07-001 (2007).

63 RMC § 201(b)(3). This RMC assumes that the threshold requirements for initial military commission jurisdiction have been met. A commission could not, for example, exercise jurisdiction to determine its jurisdiction over a non-alien or a person against whom there were no charges - or over a presumptively lawful combatant.

${ }^{64} I d$. § 948a(1)(A)(i).

${ }^{65}$ See id.; 10 U.S.C. § $948 d(\mathrm{c})$.

${ }^{66} \mathrm{RMC} \S 907(\mathrm{~b})(1)(\mathrm{A})$.
} 
substantive definition of unlawful combatant status ${ }^{67}$ (definition (i)) is to be applied by the military commission in that adjudication.

Interpreted in the way suggested here, the MCA's jurisdictional regime, which might otherwise seem to pose a conundrum, is perfectly logical and legally sound. A finding of unlawful combatancy by a competent tribunal is a prerequisite to the attachment of military commission jurisdiction. That finding is dispositive for establishing that initial jurisdiction. A military commission, once lawfully seized of a case, may adjudicate combatant status to confirm or disconfirm its own jurisdiction. There is no contradiction between these two prongs of the jurisdictional regime established by the MCA.

That two-tiered jurisdictional structure established by the MCA is consistent withindeed, as we have seen, is precisely what is required by - the law of war. Consistent with the legal presumption of lawful combatant status embodied in Article 5 of the POW Convention and Article 45(1) of Protocol I, a competent tribunal determination of unlawful combatant status is prerequisite to the attachment of military commission jurisdiction. And, as required by Article 45(2), a detainee, held as a non-POW, who is to be tried for an offense arising out of the hostilities, receives a de novo, judicial adjudication of status - by the military commission-if he asserts POW status. The MCA, thus interpreted, is internally consistent and fully in keeping with the two-tiered status determination system required by the law of war.

Fundamental canons of statutory interpretation require that the MCA be so interpreted. The Supreme Court stated in the Charming Betsy case that, “An act of Congress ought never to be construed to violate the law of nations if any other possible construction remains."68 The Court has reiterated repeatedly, in the two centuries since deciding Charming Betsy, that

\footnotetext{
${ }^{67} 10$ U.S.C. § 948a(1)(A)(i),

${ }^{68}$ Murray v. Schooner Charming Betsy, 6 U.S. (2 Cranch) 64, 118 (1804).
} 
statutory ambiguity should be resolved consistently with international law, when that is possible. ${ }^{69}$ There is indeed ambiguity in the wording of the MCA's provisions on personal jurisdiction. And that ambiguity is readily resolved in a manner consistent with the international law of war. Not only is this construction of the MCA required by the Charming Betsy canon but, as will be discussed shortly, the alternative interpretations lead to untenable results.

\section{The Jurisdictional Rulings of the Guantanamo Military Commissions and the Court of Military Commissions Review}

The interpretation of the MCA's jurisdictional framework remains highly contested. The jurisdictional rulings to date, in addition to varying between cases, have tended to be internally inconsistent, and inconsistent with both the MCA and the law of war.

\section{A. Litigating Jurisdiction in U.S. v. Khadr}

On June 4, 2007, the Guantanamo military commission presided over by military judge Peter Brownback convened for the arraignment of detainee Omar Khadr. Acting on his own motion, Judge Brownback dismissed Khadr's charges for lack of personal jurisdiction. Judge Brownback's remarkable ruling warrants reproduction in full. He ruled as follows:

1. A military commission is a court of limited jurisdiction. The jurisdiction is set by statute—-the Military Commissions Act of 2006 (MCA).

2. Section 948d establishes the jurisdiction of a military commission. 948d(a) states:

(a) JURISDICTION.-A military commission under this chapter shall have jurisdiction to try any offense made punishable by this chapter ... when committed by an alien unlawful enemy combatant.

3. Section 948d(b) specifically states that military commissions "shall not have jurisdiction over lawful enemy combatants.”

4. Thus, in the MCA, Congress denominates for the purpose of establishing jurisdiction two categories of enemy combatants - lawful and unlawful. A military commission only has jurisdiction to try an unlawful enemy combatant.

\footnotetext{
${ }^{69}$ See, e.g., F. Hoffman-La Roche, Ltd v. Empagran S.A., 542 U.S. 155, 164 (2004); McCulloch v. Sociedad Nacional de Marinos de Honduras, 372 U.S. 10 (1963); Lauritzen v. Larsen, 345 U.S. 571, 578 (1953).
} 
5. Further, in Section 948d(c), Congress stated that a finding by a Combatant Status Review Tribunal (CSRT) [or other competent tribunal] that a person is an unlawful enemy combatant is dispositive for purposes of jurisdiction by military commissions.

6. In considering Section 948d, it is clear that the MCA contemplates a two-part system. First, it anticipates that there shall be an administrative decision by the CSRT [or other competent tribunal] which will establish the status of a person for purposes of the MCA. The CSRT [or other competent tribunal] can find, for MCA purposes, that a person is a lawful enemy combatant or an unlawful enemy combatant.

7. Second, once the CSRT [or other competent tribunal] finds that a person is an unlawful enemy combatant, the provisions of the MCA come into play. Such person may have charges sworn against him, those charges may be referred to a military commission for trial, and a military commission may try him. A strict reading of the MCA would appear to require that, until such time as a CSRT (or other competent tribunal) makes a finding that a person is an unlawful enemy combatant, the provisions of the MCA do not come into play and such person may not be charged, charges may not be referred to a military commission for trial, and the military commission has no jurisdiction to try him.

8. There is, of course, the counter-argument. The military commission itself is a competent tribunal $(948 \mathrm{~d}(\mathrm{c}))$ to determine if a person brought before it is an unlawful enemy combatant. While appealing, this argument has two major flaws:

a. First, in order to make the determination, the military judge would have to conduct a mini-trial to decide if the person is an unlawful enemy combatant. Or would s/he? Perhaps, since this determination might require factual determinations, the panel would have to make it. Congress provided in the MCA for many scenarios - none anticipated that the military commission would make the lawful/unlawful enemy combatant determination.

b. Second, a person has a right to be tried only by a court which he knows has jurisdiction over him. If the military commission were to make the determination, a person could be facing trial for months, without knowing if the court, in fact and in law, had jurisdiction.

9. Persons familiar with the court-martial system might state that jurisdiction is always assumed by the court-martial and it is attacked only by motion. That is true, but a court-martial is a different creature than a military commission. A soldier is in court in uniform with her first sergeant and company commander (who most likely preferred the charges) sitting in the courtroom. DD Form 458, the Charge Sheet, contains the following information in Block I - Personal Data: Name of accused, SSN, Grade or Rank, Pay Grade, Unit or Organization, Initial Date and Term of Current Service, Pay Per Month, Nature of Restraint of 
Accused, and Date(s) Imposed. So when a military judge at Fort Bragg looks at the Charge Sheet and the accused (Who is in uniform.), she knows that Private First Class William B. Jones is a member of Bravo Company, $3^{\text {rd }}$ Battalion (Airborne), $325^{\text {th }}$ Parachute Infantry Regiment, $82^{\text {nd }}$ Airborne Division, Fort Bragg, North Carolina. She knows how much he is being paid, if he has been restrained, when he came on active duty this tour, and by comparing the unit to the name of the accuser in Block III - Preferral - she can see if it was PFC Jones' company commander who preferred the charges.

10. Contrast this with the information on MC Form 458 in this case. The military judge is told that the name of the accused is Omar Ahmed Khadr. Three aliases are given. And, the last four of an unidentified acronym, the ISN, are given. There is nothing on the face of the charge sheet to establish or support jurisdiction over Mr. Khadr, except for a bare allegation in the wording of the Specifications of the Charges

11. The military judge is not ruling that no facts could be properly established concerning Mr. Khadr which might fit the definition of an unlawful enemy combatant in Section 948a(a) of the MCA. The military judge is ruling that the military commission is not the proper authority, under the provisions of the MCA, to determine that Mr. Khadr is an unlawful enemy combatant in order to establish initial jurisdiction for this commission to try Mr. Khadr.

12. The military judge is not ruling that Mr. Khadr may not, if his case is referred to trial after a proper determination, attack those facts in the elements of the offenses referred which might combine to show him to be an unlawful enemy combatant. Such an attack is a proper part of a military commission.

13. The military judge is not ruling that the charges against Mr. Khadr must be resworn. That would seem to be the more prudent avenue to take, but that issue is not currently before this commission.

14. If there were no two-step process required to try a person under the MCA, then a prosecutor could swear charges, the convening authority could refer charges, and a military commission could try a person who had had no determination as to his status whatsoever. That is not what Congress intended to establish in the MCA.

16. The charges are dismissed without prejudice.

Peter E. Brownback III

COL, JA, USA

Military Judge 
Judge Brownback’s lucid ruling is consistent with the law of war and with a proper interpretation of the MCA. It does not, though, fully explicate its reasons or its connections to those sources of law.

In response to Judge Brownback’s dismissal of the charges against Khadr, the Government moved for reconsideration. When Judge Brownback denied that motion, the Government appealed Judge Brownback’s decision to the CMCR.

On September 24, 2007, the CMCR issued its opinion—-the first issued by that courtoverturning in part and upholding in part Judge Brownback's ruling. ${ }^{70}$ The CMCR affirmed the portion of Judge Brownback’s ruling holding that a determination of “enemy combatant status" is not equivalent to a determination of "unlawful enemy combatant status" and, so, cannot suffice as a basis for military commission jurisdiction under the MCA. ${ }^{71}$

The CMCR reversed the portion of Judge Brownback’s ruling holding that a military commission may not exercise jurisdiction absent a prior finding of unlawful combatant status by a competent tribunal. ${ }^{72}$ The CMCR opined that Judge Brownback had erred "in concluding that a [competent tribunal] determination of 'unlawful enemy combatant' status was a prerequisite to referral of charges to a military commission and [in concluding] that ... he [Judge Brownback] lacked authority under the MCA to determine whether Mr. Khadr is an 'unlawful enemy combatant' for purposes of establishing the military commission's initial jurisdiction to try him., ${ }^{73}$

\footnotetext{
${ }^{70}$ United States v. Khadr, CMCR Case No. 07-001 (Sep. 24, 2007).

${ }^{71}$ Id., at 16.

For explanation of the CSRT-related matter that the CMCR upheld, see supra note 44.

${ }^{72} I d$. at 18 .

${ }^{73}$ Id. at $18-20$.
} 
The relevant portion of the CMCR opinion is as follows:

In our opinion, the M.C.A. is clear and deliberate in its creation of a bifurcated methodology for establishing an accused's "unlawful enemy combatant" status so as to permit that individual's trial before a military commission. These two methods are laid out in M.C.A. § 948a(1)A where an "unlawful enemy combatant” is defined as:

(i) a person who has engaged in hostilities or who has purposefully and materially supported hostilities against the United States or its co-belligerents who is not a lawful enemy combatant (including a person who is part of the Taliban, al Qaeda, or associated forces); or

(ii) a person who, before, on, or after the date of the enactment of the Military Commissions Act of 2006, has been determined to be an unlawful enemy combatant by a Combatant Status Review Tribunal or another competent tribunal established under the authority of the President or the Secretary of Defense.

The disjunctive "or" between subsections (i) and (ii) clearly sets forth alternative approaches for establishing military commission jurisdiction. The military judge did not apply the disjunctive separation of these two provisions, and erroneously interpreted the distinct provisions as if written in the conjunctive; that is, as if joined by the word "and" rather than "or." Such an interpretation would render subsection (i) nothing more than a definition in aid of a C.S.R.T. (or other competent tribunal) determination of combatant status under subsection (ii), and is contradictory to the statute's clear structure, wording, and overall intent.

Upon challenge, the first method by which the M.C.A. contemplates jurisdiction being established is by evidence being presented before the military judge factually establishing that an accused meets the definition of "unlawful enemy combatant" as contained in subsection (i).... There is a long and welldeveloped tradition in US federal courts and, specifically, throughout military court-martial jurisprudence of military judges deciding matters of personal jurisdiction. Congress ... would not have deprived military commissions of the ability to independently decide personal jurisdiction absent an express statement of such intent. No such statement is contained anywhere in the M.C.A.

The military judge's reliance on M.C.A. § 948a(1)(A)(ii) for the proposition that a military commission itself cannot determine personal jurisdiction is misplaced. This provision supports Appellant's position rather than detracts from it. Although Congress assigned a jurisdictional "safe harbor" for prior C.S.R.T. (or other competent tribunal) determinations of "unlawful enemy combatant" status by statutorily deeming them "dispositive" of jurisdiction, it did not in any way preclude Appellant from proving jurisdiction before the military commission in 
the absence of such a determination. Indeed, the existence of a statutorily recognized path to achieve a "dispositive" determination of jurisdiction suggests that pretrial procedures and pleadings alleging jurisdiction should simply be viewed as "nondispositive." Subsection (ii) does not eliminate traditional methods of proving jurisdiction before the commission itself. We agree with Appellant's suggestion that Congress, through subsection (ii), merely carved out an exception to the military commission's authority to itself determine jurisdictional matters. As Appellant notes, subsection (ii) makes it clear that the military judge is not at liberty to revisit a C.S.R.T.'s (or other competent tribunal's) finding of "unlawful enemy combatant" status when there is such a finding. However, nothing in the M.C.A. requires such a finding in order to establish military commission jurisdiction. Had they so intended, Congress could have clearly stated in the M.C.A. that the only way to establish military commission jurisdiction is through a prior C.S.R.T. (or other competent tribunal) determination of "unlawful enemy combatant” status. It did not. Accordingly, we may properly find -- as clearly indicated in the language of M.C.A. $\S \S 949 a(a)$ and 948b(c) -- that Congress intended for military commissions to "apply the principles of law" and "the procedures for trial [routinely utilized] by general courts-martial ....” This would include the common procedures used before general courts-martial permitting military judges to hear evidence and decide factual and legal matters concerning the court's own jurisdiction over the accused appearing before it.

This view is supported in the Rules for Military Commissions, which provide exactly such procedures. . . . Clearly, these rules contemplate potential litigation of personal jurisdictional issues by the military commission, and provide the procedures necessary to address such a challenge. If the only avenue to achieve military commission jurisdiction was through a previously rendered C.S.R.T. (or other competent tribunal) determination of "unlawful enemy combatant" status, all of these rules would be superfluous, as "dispositive" jurisdiction would have attached before the fact.

The text, structure, and history of the M.C.A. demonstrate clearly that a military judge presiding over a military commission may determine both the factual issue of an accused's "unlawful enemy combatant status" and the corresponding legal issue of the military commission's in personam jurisdiction. A contrary interpretation would ignore the bifurcated structure of M.C.A. § 948(1)(A) and the long-standing history of military judges in general courts-martial finding jurisdictional facts by a preponderance of the evidence, and resolving pretrial motions to dismiss for lack of jurisdiction. The M.C.A. identifies two potential jurisdiction-establishing methodologies based upon an allegation of "unlawful enemy combatant” status. The first, reflected in § 948a(1)(A)(i), involves the clear delineation of the jurisdictional standard to be applied by a military commission in determining its own jurisdiction. The second, contained in $\S$ 948a(1)(A)(ii), involves a non-judicial related jurisdictional determination that is to be afforded "dispositive" deference by the military commission. Either 
method will allow the military commission's exercise of jurisdiction where "unlawful enemy combatant" status has been established by a preponderance of the evidence. This interpretation is consistent with the requirements of both the M.C.A. and with international law. See Murray v. Schooner Charming Betsy, 6 U.S. (2 Cranch) 64, 118 (1804) (acts of Congress will generally be construed in a manner so as not to violate international law, as we presume that Congress ordinarily seeks to comply with international law when legislating). ${ }^{74}$

The CMCR opinion, as is demonstrated below, interprets the MCA inconsistently with the law of war. In so doing, it fails to fulfill the Charming Betsy canon—-that an ambiguous provision in a statute should be interpreted consistently with international law, if possible. The opinion, by interpreting the MCA to limit the jurisdiction of military commissions to determine their own jurisdiction, also poses a significant problems concerning core principles of judicial jurisdiction. These two areas of difficulty are examined below, after a brief consideration of the set of logically-possible interpretations of the MCA that were available to the CMCR.

While the CMCR reached what it viewed as the best available outcome in Khadr, the court expresses discomfort at several points in the opinion with the conclusions it reaches—or, at least, notes drawbacks in those conclusions and their ramifications. Certain available interpretations of the MCA's jurisdictional framework are not considered in the CMCR opinion and, perhaps, were not apparent to the CMCR as it reached its decision. Those options are identified and evaluated below.

In examining the interpretations of the MCA that were available to the CMCR, recall that the MCA's “Jurisdiction” section, as noted earlier, states: “A finding . . . by a . . . competent tribunal ... that a person is an unlawful enemy combatant is dispositive for purposes of jurisdiction for trial by military commission. . .,”75

Recall, also, that the Act's "Definitions” section provides that:

\footnotetext{
${ }^{74} \mathrm{Id}$. at 21-25 (some internal citations omitted).

${ }^{75} \S 948 \mathrm{~d}(\mathrm{~b})$.
} 
(1)(A) The term 'unlawful enemy combatant' means-

"(i) a person who has engaged in hostilities or who has purposefully and materially supported hostilities against the United States or its cobelligerents who is not a lawful enemy combatant (including a person who is part of the Taliban, al Qaeda, or associated forces);

or

" (ii) a person who, before, on, or after the date of the enactment of the Military Commissions Act of 2006, has been determined to be an unlawful enemy combatant by a Combatant Status Review Tribunal or another competent tribunal established under the authority of the President or the Secretary of Defense. ${ }^{76}$

Those provisions are facially ambiguous on two questions: Is a competent tribunal determination of unlawful combatancy a prerequisite to initial military commission jurisdiction? And, does a competent tribunal determination of unlawful combatancy (“dispositive” under $\S$ 948d(c)) preempt determination of combatant status by a military commission? The possible answers to those questions create four logical possibilities for interpreting the MCA. The Table below presents those four possible interpretations.

${ }^{76} \S$ 948(a)(1). 


\section{Possible InTerpretations of MCA Provisions on Personal JuRisdiction}

Competent Tribunal Determination Is Not Prerequisite to M.C. Jurisdiction

Is Prerequisite
Competent Tribunal

Determination Preempts Status

Determination by M.C.*

\begin{tabular}{l|l}
$\begin{array}{l}\text { 1) } \\
\text { Violates MCA and law of war } \\
\text { by permitting the attachment } \\
\text { of M.C. jurisdiction to a } \\
\text { presumptively lawful } \\
\text { combatant; }\end{array}$ & $\begin{array}{l}\text { 2) } \\
\text { RCA's provisions on } \\
\text { violates Article 45(2) by } \\
\text { competent tribunals. }\end{array}$ \\
$\begin{array}{l}\text { denying a judicial status } \\
\text { adjudication to a detainee who } \\
\text { is held as a non-POW and is to } \\
\text { be tried for an offense arising } \\
\text { out of the hostilities; and, } \\
\text { strips military commissions of } \\
\text { courts' inherent power to } \\
\text { determine their own } \\
\text { jurisdiction. }\end{array}$ \\
$\begin{array}{l}\text { 3) } \\
\text { Violates Article 45(2) by } \\
\text { denying a judicial status } \\
\text { adjudication to a detainee who } \\
\text { is held as a non-POW and is to } \\
\text { be tried for an offense arising } \\
\text { out of the hostilities; and, } \\
\text { strips military commissions of } \\
\text { courts' inherent power to } \\
\text { determine their own } \\
\text { jurisdiction. }\end{array}$ \\
$\begin{array}{l}\text { Fulfills the requirements of the } \\
\text { MCA and the law of war. }\end{array}$ \\
\\
\end{tabular}

* “M.C.” indicates Military Commission. 
The interpretation represented in Cell 1 is that, under the MCA, a combatant status determination by a competent tribunal is not a prerequisite to military commission jurisdiction, and a military commission may not make a combatant status determination to ascertain its own jurisdiction if a determination of unlawful combatant status has been made by a competent tribunal. This interpretation would lead, in any given case, to one of two unlawful results. In a case where there was no competent-tribunal determination of unlawful combatant status, a presumptively lawful combatant would nevertheless be subject to military commission jurisdiction. In a case where there was a competent-tribunal determination of unlawful combatant status, a person who was held as a non-POW and was to be tried for an offense arising out of the hostilities would be denied the Article 45(2) right to a judicial adjudication of status. The interpretation presented in Cell 1 also would strip military commissions of the jurisdiction to determine their own jurisdiction, a problem to be discussed further, below.

The interpretation represented in Cell 2 is that a status determination by a competent tribunal is not a prerequisite to military commission jurisdiction, and a military commission may make a combatant status determination, to ascertain its own jurisdiction, even if a competent tribunal had previously made a determination of unlawful combatant status. This, obviously, is not what Congress intended. If a competent tribunal determination is not a prerequisite to military commission jurisdiction and a military commission may make its own combatant status determination notwithstanding a prior determination by a competent tribunal, then the entire reference in the MCA to competent tribunal determinations is superfluous. Under the interpretation represented in Cell 2, the determination of combatant status by a competent tribunal makes absolutely no difference: with or without a competent-tribunal determination, a 
military commission may exercise initial jurisdiction and may make a combatant status determination in order to ascertain its own jurisdiction.

The interpretation represented in Cell 3 is that a status determination by a competent tribunal is a prerequisite to military commission jurisdiction, and a military commission may not make a combatant status determination to ascertain its own jurisdiction if a determination of unlawful combatant status has been made by a competent tribunal. Here, consistent with the law of war, a detainee is excluded from military commission jurisdiction absent a prior determination of unlawful combatant status by a competent tribunal. But, in violation of the law of war, a detainee held as a non-POW, who is to be tried for an offense arising out of the hostilities, is denied an Article 45(2) de novo adjudication of combatant status. The interpretation represented in Cell 3 also strips military commissions of the jurisdiction to determine their own jurisdiction, as discussed further, below.

The interpretation represented in Cell 4 is that a status determination by a competent tribunal is a prerequisite to military commission jurisdiction, and a military commission may make a combatant status determination to ascertain its own jurisdiction. This interpretation offers a solution to the conundrum of jurisdiction under the MCA. It is the interpretation discussed at length in Part III, above. This interpretation of personal jurisdiction under the MCA is consistent with the law of war, consistent with the MCA read as a whole, and retains for military commissions the jurisdiction to determine their own jurisdiction. As is sketched out in the foregoing paragraphs, and discussed at greater length below, the alternative interpretations lead inevitably to a thicket of difficulties.

The CMCR, in the Khadr ruling, selects the interpretation of the MCA represented in Cell 1, holding that a competent-tribunal determination of unlawful combatant status is not a 
prerequisite to military commission jurisdiction, ${ }^{77}$ and that such a determination, if one has been made, preempts determination of combatant status by a military commission. ${ }^{78}$ That interpretation of the MCA commits the court to violations of the law of war, violations of the MCA, and impingements on the traditional jurisdictional powers of courts.

\section{International Law}

The CMCR's ruling entails several violations of the international law of war. First, by permitting the exercise of military commission jurisdiction in the absence of a competenttribunal determination of unlawful combatancy, the ruling violates the presumption of lawful combatant status embodied in Articles 5 and 45. ${ }^{79}$ The MCA provides that military commissions shall not have jurisdiction over lawful combatants. The law of war provides that a combatant held by the enemy is presumed to be a lawful combatant unless a contrary determination is made by a competent tribunal. By holding that military commission jurisdiction may attach to a detainee in the absence of a prior competent-tribunal determination of unlawful combatant status, the CMCR treats a presumptively lawful combatant as an unlawful combatant, in violation of the

\footnotetext{
${ }^{77}$ Khadr at 18.

${ }^{78}$ Id. at 24-25.
}

Under the court's interpretation, the MCA contemplates two methods for determining combatant status, either (but not both) of which may be applied in any given case: a competent-tribunal may determine combatant status or, in lieu of that, a military-commission may do so. The court does not account for what would be, under that interpretation, a curious feature of the MCA: Why, if there are two methods for determining combatant statusbefore a competent tribunal and before a military commission-is only one method mentioned in the "Jurisdiction" section? If combatant status determinations by competent tribunals and military commissions were simply two, alternative methods for determining military-commission jurisdiction, then why would the "Jurisdiction" section account for only one of them?

When the competent-tribunal status determination and the military-commission status adjudication are understood as the sequenced steps in the two-tiered system of status determination required by the law of war (specifically Article 45(2) of Protocol I), the mystery disappears: Congress needed to identify the method for determining a prior the jurisdiction-military commission or court-martial— to which a case should be submitted. Whichever jurisdiction received a particular case could then adjudicate combatant status to review its own jurisdiction, if that became appropriate, in the course of the litigation. But first, the case had to be sent to one court or the other. The MCA's “Jurisdiction” section states the method for making that initial decision.

79 Cite. 
law of war. By eroding the presumption of lawful combatant status, the opinion places in jeopardy that threshold safeguard for all POW rights and protections.

The CMCR, of course, should never have been faced with the question whether a competent-tribunal status determination is prerequisite to the exercise of military commission jurisdiction over Khadr. A detained combatant is entitled to the presumption of lawful combatancy—and, hence, POW status—-from the time he is brought into captivity until such time as that presumption is rebutted by a finding of unlawful combatancy by a competent tribunal. ${ }^{80}$ Omar Khadr was brought to Guantanamo in 2002. Like all the detainees at Guantanamo, he has been held, since the time of his capture, as a non-POW but has never had a competent-tribunal status determination. That systematic violation of the law of war, however, is beyond the scope of the present article.

The second major aspect of the CMCR ruling—that a combatant status determination by a competent tribunal, if one has been made, preempts adjudication of combatant status by a military commission - entails another violation of the law of war. The opinion explicitly acknowledges that Article 45(2) of Protocol I embodies customary international law. ${ }^{81}$ The court notes that,

Article 45(2) of Protocol I to the Geneva Conventions[] suggests that a detained individual who is not being held as a POW has the right to assert an entitlement to POW status before a judicial tribunal, and that judicial adjudication of combatant status shall occur before trial for any alleged substantive offense. ${ }^{82}$

The opinion then asserts that its interpretation of the MCA is consistent with Article 45(2), stating:

\footnotetext{
${ }^{80}$ See Art. 5; Art. 45(1).

${ }^{81}$ Khadr at 25, n. 38.

${ }^{82} \mathrm{Id}$.
} 
Following the M.C.A. procedures, as we interpret them here, would allow an accused to assert a claim of POW (i.e., lawful combatant) status at a pretrial motion session before the military judge. This pretrial determination of status would be fully in accord with Article 45(2) of Protocol I. ${ }^{83}$

But, as noted above, the opinion states elsewhere that, "[T]he military judge is not at liberty to revisit a ... competent tribunal's [] finding of 'unlawful enemy combatant' status when there is such a finding." 84 The CMCR cannot have it both ways. In holding that a military commission may not adjudicate combatant status when there has been a prior determination of unlawful combatant status by a competent tribunal, the ruling directly violates Article 45(2), even while purporting to enforce it.

The CMCR opinion does not identify or address this problem. Rather, the opinion asserts simply that the MCA, in prohibiting a military commission from 'revisiting' a competent tribunal's finding of unlawful combatant status, "has merely carved out an exception to the military commission's authority to determine jurisdictional matters.”85 But, if the CMCR interprets the MCA to require this “exception” to the requirements of Article 45(2), then the CMCR can hardly maintain, as it does, that "[t]his interpretation is consistent with the requirements of both the M.C.A. and with international law."86

The CMCR's holding that a competent tribunal determination preempts adjudication of status by a military commission leads to another infelicitous result as well. The CMCR correctly states that Article 45(2) requires that an individual who is not held as a POW is entitled, if he is to be prosecuted for an offense arising out of the hostilities, "to assert his right to prisoner-of-war status before a judicial tribunal and to have that question adjudicated." ${ }^{87}$ It stands to reason that

\footnotetext{
${ }^{83} \mathrm{Id}$.

${ }^{84} \mathrm{Id}$. at 21 (emphasis in original).

${ }^{85}$ Id. at 23.

${ }^{86} \mathrm{Id}$. at 25.

${ }^{87}$ Khadr at 25, n. 38; Protocol I, art. 45(2).
} 
the Article 45(2) entitlement to a status adjudication applies only to a detainee who is not held as a POW. There would be no logic in affording a status adjudication to a detainee already held as a POW and whose POW trial rights were, therefore, not at issue. But, in holding that a competent-tribunal determination of unlawful combatancy preempts a status adjudication by a military commission, the court specifically denies an Article 45(2) adjudication of status to every person who lawfully could be "not held as a POW." The result is absurd: only a detainee who has been determined by a competent tribunal to be an unlawful combatant is entitled to, or has any need for, a status adjudication under Article 45(2); but the CMCR's interpretation of the MCA denies a status adjudication to precisely that group of detainees.

Under the CMCR ruling, then, a detainee gets either a status determination by a competent tribunal or an Article 45(2) adjudication. If he has already had the former, he is ineligible for the latter, and vice versa. But, under the law of war, it is only if he has had the former that he has any need for the latter-and he is entitled to both. By denying each defendant either the competent tribunal determination to which he is entitled under Articles 5 and 45(1) or the judicial adjudication of status to which he is entitled under Article 45(2), the CMCR ruling generates a law-of-war violation every time that a military commission exercises jurisdiction.

The violations of the law of war that are entailed in the CMCR opinion are fundamental. Without so stating, the CMCR opinion does away with the presumption of lawful combatancy, the role of the competent tribunal as the sole means for rebutting that presumption, and the Article 45(2) right to a judicial adjudication of combatant status. If this ruling is permitted to stand, the damage to POW protections will be far-reaching.

\section{The Inherent Jurisdiction of Courts}


The interpretation of the MCA adopted by the CMCR abrogates the traditional power of courts to determine their own jurisdiction. Under the MCA, the CMCR says, a military commission is prohibited from adjudicating combatant status if a combatant status determination has been made by a competent tribunal. This, the CMCR suggests, is the meaning of the “dispositive" clause in the MCA's "Jurisdiction" section. ${ }^{88}$ The difficulties posed as a consequence of that interpretation go to fundamental principles of the inherent jurisdiction of courts.

Would a military commission, presented with new evidence proving the lawful combatant status of the accused, be required nevertheless to treat as "dispositive" the status determination made by the competent tribunal and, so, proceed with the trial of a demonstrably lawful combatant over whom it lacked lawful jurisdiction? Could a commission, deprived of the "inherent jurisdiction to determine its own jurisdiction," fulfill the requirement articulated in the MCA and in Common Article 3 of the Geneva Conventions, that a military commission be a “regularly constituted court?"89 The CMCR itself poses the related question whether such an arrangement would "deprive[] a military commission accused of a critical 'judicial guarantee[] . . . recognized as indispensable by civilized people’ under Common Article 3 of the Geneva

\footnotetext{
${ }^{88}$ MCA section 948(d)(c) reads: DETERMINATION OF UNLAWFUL ENEMY COMBATANT STATUS DISPOSITIVE A finding, whether before, on, or after the date of the enactment of the Military Commissions Act of 2006, by a Combatant Status Review Tribunal or another competent tribunal established under the authority of the President or the Secretary of Defense that a person is an unlawful enemy combatant is dispositive for purposes of jurisdiction for trial by military commission under this chapter.

${ }^{89}$ MCA section 948(b)(f) reads: STATUS OF COMMISSIONS UNDER COMMON ARTICLE 3.A military commission established under this chapter is a regularly constituted court, affording all the necessary ‘judicial guarantees which are recognized as indispensable by civilized peoples’ for purposes of common Article 3 of the Geneva Conventions.
} 
Conventions (i.e., the right to affirmatively challenge the commission's in personam jurisdiction over him). ${ }^{, 90}$

The CMCR is not heedless of the role of jurisdiction-to-determine-jurisdiction in the basic functioning of courts. Although it holds that the MCA "carves out an exception" that preempts status adjudication by a military commission if a competent tribunal has made a prior status determination, the CMCR —in holding that a competent tribunal determination is not a prerequisite to military commission jurisdiction—argues forcefully against interpreting the MCA to prohibit military commissions from adjudicating status to determine their own jurisdiction. The court observes:

[T] he M.C.A. contemplates jurisdiction being established ... by evidence being presented before the military judge factually establishing that an accused meets the definition of "unlawful enemy combatant" as contained in subsection (i).... There is a long and well-developed tradition in US federal courts and, specifically, throughout military court-martial jurisprudence of military judges deciding matters of personal jurisdiction. Congress ... would not have deprived military commissions of the ability to independently decide personal jurisdiction absent an express statement of such intent. No such statement is contained anywhere in the M.C.A.....

Congress intended for military commissions to "apply the principles of law" and "the procedures for trial [routinely utilized] by general courts-martial . . ..” This would include the common procedures used before general courtsmartial permitting military judges to hear evidence and decide factual and legal matters concerning the court's own jurisdiction over the accused appearing before it.

This view is supported in the Rules for Military Commissions, which provide exactly such procedures. ... Clearly, these rules contemplate potential litigation of personal jurisdictional issues by the military commission, and provide the procedures necessary to address such a challenge.

The ruling nevertheless, as we know, interprets the MCA to make an "exception" that does "deprive[] military commissions of the ability to independently decide personal jurisdiction” if a competent tribunal status determination has been made. Even while announcing that "exception," though, the CMCR expresses discomfort with the arrangement

\footnotetext{
${ }^{90}$ Khadr at 12, n.18.
} 
(questioning, for example, whether thus precluding a challenge to personal jurisdiction before a military commission would infringe fundamental judicial guarantees under the law of war). ${ }^{91}$ The opinion even flirts, at one point, with the suggestion that the word "dispositive" in the MCA should not be understood really to mean dispositive, saying, "Congress intended that properly made ... [competent tribunal] determinations of 'unlawful enemy combatant' status ... should be afforded great deference by the military commission." 92

But, as we have seen, a move in that direction does not offer a solution. If a competenttribunal determination were not a prerequisite to military commission jurisdiction and a military commission could make its own combatant status determination (with whatever degree of "deference"), then—as represented in Cell 2 in the Table above—-the competent tribunal determination would be meaningless; with or without a competent-tribunal determination, a military commission would be authorized to exercise initial jurisdiction and to adjudicate combatant status. ${ }^{93}$ Under that interpretation, the most that could be said about a competent tribunal determination is that, if one happens to exist, it should be taken into account by the military commission when it determines its jurisdiction.

In its 2007 ruling in U.S. v. Khadr, the CMCR has adopted an extremely problematic interpretation of the MCA—with which, it seems, the court itself is not entirely comfortable. Perhaps the court did not consider — and, in any event, it did not adopt—a far less problematic, alternative interpretation that was, and remains, available to it. ${ }^{94}$

\footnotetext{
${ }^{91}$ See text accompanying note 58.

${ }^{92}$ United States v. Khadr, CMCR Case No. 07-001, at 12 n.18 (emphasis added).

${ }^{93}$ See supra pp. 27-31.

${ }^{94}$ Madeline Morris, Frank Fountain, Allison Hester-Haddad, Steven Bornick, and Landon Zimmer filed an amicus brief with the CMCR in the Khadr case delineating an early version of the interpretation represented in Cell 4. See Brief of Amicus Curaie (ARTicle 45 of Protocol I to GeneVA CONVENTIONS AND STATUTORY CONSTRUCTION OF THE MilitARy COMmissions ACt OF 2006) in U.S. v. Khadr, CMCR Case. No. 07-001 (2007) available at: http://www.defenselink.mil/news/Aug2007/13Khadr\%20Amicus\%20Brief\%20(Aug\%2021)\%20(27\%20pages).pdf.
} 


\section{B. Litigating Jurisdiction in U.S. v. Hamdan}

The difficulties entailed in the CMCR's Khadr opinion are regenerated in the December 17, 2007 ruling in U.S. v. Hamdan, the first jurisdictional ruling by a military commission seeking to apply the Khadr precedent. The December 17 ruling also has a very perplexing feature: it is flatly inaccurate in both its quotation and its citation of sources.

On the same day as Omar Khadr’s charges were dismissed for lack of personal jurisdiction by Judge Brownback, Judge Keith Allred dismissed, for lack of personal jurisdiction, the charges against Salim Hamdan—the only other military commission defendant then charged. ${ }^{95}$ The Government moved for reconsideration. Judge Allred granted the govenrment's motion shortly after the CMCR issued its decision in Khadr. Hamdan, thereupon, submitted a motion challenging the personal jurisdiction of the military commission and requesting an Article 5 status determination by a competent tribunal. Hamdan's motion requesting an Article 5 status determination made no mention of Article 45; and it made no mention of the requirement, discussed earlier, ${ }^{96}$ that a competent tribunal be composed of more than one person.

On December 5, 2007, Judge Allred heard oral argument on the motion for an Article 5 competent-tribunal determination of combatant status. And, on December 6, he conducted an evidentiary hearing on Hamdan's combatant status. The evidentiary hearing was held in order that, if he decided to grant the motion for an Article 5 status determination by a competent tribunal—and if he decided, further, that he himself could serve as that competent tribunal—he would be prepared to render the combatant status determination forthwith.

\footnotetext{
${ }^{95}$ See United States v. Hamdan, Order on Motion to Dismiss for Lack of Jurisdiction (Allred, J.), MCOO \# 07-04, (June 4, 2007), at http://www.nimj.com/documents/Hamdan\%20Order.pdf.

96 See supra at 6-7.
} 
Judge Allred ruled on Hamdan's motion for an Article 5 status determination on December 17, 2007.97 (The ruling is reproduced in full at Appendix A, below.) The ruling, ostensibly granting the motion for an Article 5 tribunal, states that Judge Allred will conduct a hearing "to determine whether the accused is an alien unlawful enemy combatant, and therefore subject to the Commission's jurisdiction," ${ }^{, 98}$ and that the same, single hearing "will also determine his status for the purposes of Article 5."99 That outcome violates the law of war and, in turn, the Charming Betsy canon.

The holding, moreover, appears to rest, ultimately, on a purported waiver of certain rights afforded under the POW Convention. ${ }^{100}$ POW rights are not waivable. For the commission to give legal effect to such a purported waiver is a violation of the law of war.

But there is an additional and more perplexing problem in the December 17 Hamdan ruling. The ruling misstates both the meaning and the actual text of the authorities on which it relies.

Article 5, recall, provides for the presumption of POW rights and for a combatant status determination by a competent tribunal in case of doubt. Article 45 of Protocol I, in paragraph 1 , reiterates the presumption of POW status and the right to a competent tribunal determination and, in paragraph 2, articulates the right to a judicial adjudication of combatant status for a detainee not held as a POW who is to be tried for crimes arising out of the hostilities.

The December 17 Hamdan ruling moves toward its conclusion—-that an Article 5 competent-tribunal proceeding and an Article 45(2) status adjudication will be collapsed into one

\footnotetext{
${ }^{97}$ United States v. Hamdan, Ruling on Defense Motion for Article 5 Status Determination (Allred, J.), (Dec. 17, 2007), also available at http://www.defenselink.mil/news/Dec2007/HAMDAN\%20ARTICLE\%205\%20RULING\% 2017\%20Dec\%202007.pdf.

${ }^{98} I d$. at 4 .

${ }^{99} \mathrm{Id}$.

${ }^{100}$ See infra pp. 4-13.
} 
proceeding, conducted by Judge Allred-by a progressive blurring of the distinction between

Article 5 and Article 45.

After quoting Article 5 in full, the ruling presents an inaccurate quotation that is purported to support the proposition that the Article 5 and Article 45 proceedings may be collapsed into one proceeding. The actual text of the source "quoted," in fact, decisively rejects that proposition.

The misquoted materials are drawn from Howard S. Levie’s Code of International Armed Conflict. ${ }^{101}$ It is the sole secondary source relied upon in the ruling. ${ }^{102}$

The ruling states:

Referring to Article 5, Howard S. Levie writes, “The present article was an attempt to eliminate, or at least to reduce, the number of instances in which military personnel in the field make an arbitrary decision that a captured individual is an illegal combatant and impose summary justice. . . . . [it] assures the accused not only of a determination by a competent tribunal, but of a further judicial tribunal-but only if the detaining power proposes to try him for an offense arising out of hostilities."

The ruling misstates both the text and the meaning of the Levie passage. The language presented in the ruling as a quotation is, in fact, an amalgam of language from two different subsections of the Levie book, with critical headings and sentences omitted, and interspersed with words that appear nowhere in the Levie text.

\footnotetext{
${ }^{101}$ Howard S. Levie, Code of International Armed Conflict (1986). At the US Naval War College, Howard Levie held the Stockton Chair of International Law in 1971-1972 and, later, was made “Adjunct Professor for Life.” The Naval War College's "Howard S. Levie Chair of Military Operational Law” was named to honor his contributions to the field.

${ }^{102}$ The ruling makes reference also to the official Commentaries to the Geneva Conventions. Because the Commentaries are the official (though non-binding) elaboration of the Geneva Conventions, they are not a "secondary" source in the present sense. See

${ }^{103}$ United States v. Hamdan, Ruling on Defense Motion for Article 5 Status Determination (Allred, J.), (Dec. 17, 2007), at 2 (citing HowARD S. LeVIE, I THE CODE OF InTERNATIONAL ARMED CONFLICT 305-06 (1986)) (emphasis in ruling).
} 
The ruling's quotation of the language appearing before the ellipsis accurately reproduces Levie’s Comment on Article-5 tribunals. ${ }^{104}$ The trouble begins after the ellipses.

The ruling presents the Levie material as one quotation "referring to Article 5," when, in fact, the language after the ellipses is drawn from a separate subsection of the book, concerning Article 45(2). Between the sentence before the ellipses in the ruling and the sentence after the ellipses, the original text contains: (1) a heading indicating that Levie is no longer talking about Article 5 “competent tribunal” at all but, rather, has moved to a discussion of an Article 45(2) “judicial tribunal”; ${ }^{105}$ (2) a full quotation of Article 45(2); ${ }^{106}$ (3) a free-standing paragraph, reading “SOURCE: Article 45(2), 1977 Protocol I;”,107 and, (4) several critical sentences of commentary distinguishing between the requirements of Article 5 and Article $45 .^{108}$ (Images of the cited pages of the Levie text appear at pages 49-50, below.)

The alterations of the Levie text extend beyond those structural features of the text. The ruling omits ten words and adds twelve words to the sentence that appears after the ellipses. The passage, as written by Levie, reads: "It assures him of a further determination of that question, this time by a judicial tribunal. . ."109 The passage as presented in the ruling states: "[it] assures the accused not only of a determination by a competent tribunal, but of a further judicial tribunal. . .."110

The differences between those words add up to more than the sum of their parts. Levie’s actual language: a “further [i.e., additional] determination of that question [i.e.,

\footnotetext{
${ }^{104}$ See HowARD S. LEVIE, I THE CODE OF InTERnATIONAL ARMED CONFLICT 305 (1986) (the language in question appears in the “COMMENT on 741.8”).

${ }^{105}$ See id., at 305.

${ }^{106} \mathrm{Id}$.

${ }^{107} I d$., at 306.

${ }^{108}$ See id. (the language in question appears in the "COMMENT on 741.9”). ${ }^{109}$ Id.

${ }^{110}$ United States v. Hamdan, Ruling on Defense Motion for Article 5 Status Determination (Allred, J.), (Dec. 17, 2007), at 2 (emphasis in ruling).
} 
combatant status], this time [i.e., a second "time”] by a judicial tribunal” clearly reflects the two-step procedure required under Article 45. This point is obfuscated in the words presented in the ruling, which replace Levie's clear language with the ambiguous locution, "not only of a determination by a competent tribunal, but of a further judicial tribunal.”

At least as significant as the inaccuracies in the language that is "quoted" are the parts of the Levie passage that are omitted. The ruling omits from the passage two sentences that run directly and actively contrary to the proposition that the Article 5 and Article 45(2) proceedings may be collapsed into one. The excised sentences state:

The present article [45(2)] presupposes that the "competent tribunal" of Articles [5 and 45(1)] has determined the individual concerned [was] not entitled to prisoner-of-war status. ...

It is unfortunate that the draftsmen used the phrase "is not held as a prisoner of war," rather than using words stating expressly that "a competent tribunal has determined that he is not entitled to prisoner-of-war status."111

In other words, in material omitted from the passage, Levie explicitly states—and restates - that Article 45(2), in providing for a judicial adjudication of status, presupposes that there has been a prior determination of unlawful combatant status by a competent tribunal. Levie's actual passage explicitly states that the international law of war requires a combatant status determination by a competent tribunal, to be followed by "a further determination of that question, this time, by a judicial tribunal”112 if the detainee is to be prosecuted for war crimes. Levie, in the actual passage, even offers a clearer wording to express the content of Article 45(2), lest his reader fail to grasp that a competent tribunal determination of combatant status is a necessary precursor to the operation of Article 45(2). The unmistakable import of Levie's

\footnotetext{
${ }^{111}$ LEVIE, supra note 95, at 306 (within the “COMMENT”) (emphasis added).

${ }^{112}$ LEVIE, supra note 95, at 306.
} 
language is that the Article 5 and Article 45 status determinations may not be collapsed into one proceeding.

The following two pages are images of the cited pages of the Levie text.

(NB: Howard Levie, for purposes of his "Code" of commentaries on the law of war, assigned his own system of article numbers to the provisions of the Geneva Conventions and the Protocols Additional to the Geneva Conventions. The cross-references from his numbering to the numbering in the POW Convention and Protocol I are indicated at the relevant points.) 
COMMENT: See the COMMENT under Article 622.1 of this Code.

741.8. PRISONERS OF WAR. ENTITLEMENT TO

STATUS. DETERMINATION BY COMPETENT

TRIBUNAL.

Should any doubt arise as to whether persons, having committed a belligerent act and having fallen into the hands of the enemy, belong to any of the categories enumerated in Articles 123.3, 1123.2, and 1231.8 of this Code, such persons shall enjoy the protection of the provisions hereof relating to prisoners of war until such time as their status has been determined by a competent tribunal.

SOURCE: Article 5(2), 1949 Third Convention.

COMMENT: The present article was an attempt to eliminate, or at least to reduce, the number of instances in which military personnel in the field make an arbitrary decision that a captured individual is an illegal combatant and impose summary justice. Concerning instances of its application see: Levie, Prisoners of War 55-57; Levie, Documents $694,722,732,737,757$ and 771 .

The provisions of this article have been somewhat extended by Article 45(1) and 2 of the 1977 Protocol I (Articles 741.3 and 741.9. respectively, hereof).

741.9. PRISONERS OF WAR. ENTITLEMENT TO STATUS. DETERMINATION BY JUDICIAL TRIBUNAL.

If a person who has fallen into the power of an adverse Party is not held as a prisoner of war and is to be tried by that Party for an offense arising out of the hostilities, he shall have the right to assert his entitlement to prisoner-of-war status before a judicial tribunal and to have that question adjudicated. Whenever possible under the applicable procedure, this adjudication shall occur before the trial for the offence. The representatives of the Protecting Power shall be entitled to attend the proceedings in which the question is adjudicated, unless, exceptional1y, the proceedings are held in camera in the 


\begin{tabular}{|c|c|}
\hline $\begin{array}{l}\text { Cross-reference } \\
\text { to Article } 45 \text { of } \\
\text { Protocol I and } \\
\text { Article } 5 \text { of the } \\
\text { POW Convention }\end{array}$ & $\begin{array}{l}\text { SOURCE: Article 45(2), } 1977 \text { Protocol I. } \\
\text { COMMENX. The present article presupposes that the "competent } \\
\text { ribunal" of Articles } 141.3 \text { and } 141.8 \text { of this Code has determined that }\end{array}$ \\
\hline & $\begin{array}{l}\text { the individual concerned did not come within the purview of Articles } \\
123.1,123.2,123.3 \text {, or } 741.2 \text { hereof and was, therefore, not entitled to } \\
\text { prisoner-of-war status. It assures him of a further determination of } \\
\text { that question, this time by a judicial tribunal - but only if the }\end{array}$ \\
\hline $\begin{array}{l}\text { Cross-reference } \\
\text { to Article } 4 \text { of } \\
\text { the POW } \\
\text { Convention and } \\
\text { Articles } 43 \& \\
44 \text { of Protocol I }\end{array}$ & $\begin{array}{l}\text { It is unfortunate that the draftsmen used the phrase "is not held } \\
\text { hostilities. (Presumably, this means a pre-capture offense.) } \\
\text { as a prisoner of war," rather than using words stating expressly that "a } \\
\text { competent tribunal has determined that he is not entitled to prisoner- } \\
\text { of-war status." In both North Korea and North Vietnam the assertion was } \\
\text { made that individuals captured by the Communist side "were not held as } \\
\text { prisoners of war," but as war criminals. Despite the clear intention of } \\
\text { the article, it can be assumed that in any future armed conflict those, }\end{array}$ \\
\hline & $\begin{array}{l}\text { and like-minded, countries will repeat the prior assertion and claim } \\
\text { that the language of this article justifies their action. } \\
\text { There have been a number of comparatively recent instances in which } \\
\text { judicial tribunals have passed on the question of entitlement to } \\
\text { prisoner-of-war status in connection with a trial for a pre-capture } \\
\text { offense. See Levie, Documents, } 732 \text {, } 737 \text {, } 757 \text {, and } 771 \text {. All of those } \\
\text { cases were, however, concerned with the provisions of Article } 741.8 \\
\text { hereof. rather than those of the present article. }\end{array}$ \\
\hline
\end{tabular}

741. 10. PRISONERS OF WAR. PERSONS TAKING

PART IN HOSTILITIES. PROTECTION IF NOT ENTITLED TO STATUS.

Any person who has taken part in hostilities, who is not entitled to prisonerof-war status and who does not benefit from more favourable treatment in accordance with the provisions of this Code relating to the protection of civilians shall have the right at all times to the protection of Articles $711.4,713.13,1332.61362 .3,1362.4,1362.5$ and 1365.2 of this Code. In occupied territory, any such person, unless he is held as a spy, shall also be entitled, notwithstanding Article 1123.3 hereof, to his rights of communication in accordance with the aforementioned provisions of this Code. 
After the Levie material is presented as concerning Article 5-with no mention of Article 45-the next paragraph of the ruling begins the words: "Discussing the same provision," ${ }^{, 13}$ and proceeds with a discussion of status determinations under Article 5. In the subsequent paragraph, the ruling states:

When the drafters sought to clarify when such a determination should be made, there was disagreement. "In view of the great differences in national justice procedures, it was not thought possible to establish a firm rule that this question [an accused's status] must be decided before the trial for the offense, but it should be so decided if at all possible, because on it depends the whole array of procedural protections accorded to Prisoners of War, by the Third Convention, and the issue may go to the jurisdiction of the tribunal.” Yves Sandoz et. al, eds. Commentary on the Additional Protocols of 8 June 1977 to the Geneva Conventions of 12 August 1949, International Committee of the Red Cross (Geneva 1987) at 556. ${ }^{114}$

But that quoted paragraph, presented as concerning "the drafters" of Article 5, in fact has nothing to do with Article 5 or its drafters. Rather, the passage quoted is from the Commentary to Article 45(2) of Protocol I. Inexplicably, while presented in the ruling as a discussion of "the same provision” (referring to Article 5), the quotation is correctly cited in the ruling as coming from the Commentary to Protocol I. Even that citation, however, makes no mention of Article 45.

The conflation of Articles 5 and 45 is, by now, complete-and lays the groundwork for the holding that, "The hearing [that] the Commission will undertake to determine whether the accused is an alien unlawful enemy combatant, and therefore subject to the Commission's jurisdiction[,] will also determine his status for the purposes of Article 5."115

The two-for-one solution reached in the December 17 Hamdan ruling is inconsistent with the law of war and with a proper interpretation of the MCA. Both of those sources of law demand a competent tribunal determination of unlawful combatant status as a prerequisite to

\footnotetext{
${ }^{113}$ United States v. Hamdan, Ruling on Defense Motion for Article 5 Status Determination (Allred, J.), (Dec. 17, 2007), at 2 .

${ }^{114} \mathrm{Id}$

${ }^{115} \mathrm{Id}$. at 4 .
} 
military commission jurisdiction; and, both require a subsequent judicial adjudication of combatant status for a detainee who is held as a non-POW and is to be tried for crimes arising out of the hostilities."116

The December 17 ruling commits a second serious violation of the law of war, briefly mentioned earlier. The ruling unlawfully relies on a “concession” by the defense as a waiver of Hamdan's right to an Article 5 competent tribunal composed of more than one person. Rights under the POW Convention are absolutely non-waivable. ${ }^{117}$ No purported waiver of rights under the POW Convention may lawfully be given effect. ${ }^{118}$

At the time of the December 17, 2007 ruling, Hamdan was entitled to the rights afforded under the POW Convention. As Judge Allred himself noted in the ruling, “[b]ecause the accused has not yet been determined to be an alien unlawful enemy combatant by any tribunal, this section [MCA $\S 948 b(\mathrm{~g})]$ does not apply to defeat his right to rely on the Geneva Conventions for the purposes of determining his status.”, 119

Central among those POW-Convention rights was Hamdan’s right to presumptive lawful combatant status unless and until a contrary determination was made by a competent tribunal. Judge Allred correctly states that a qualified Article-5, competent tribunal must be composed of more than one person. ${ }^{120}$ Indeed, Judge Allred observes that, in the drafting of Article 5, the text was amended to employ the term "military tribunal” rather than "competent authority,” to reflect precisely this composition requirement. As Judge Allred notes, “[t]his amendment was based on

\footnotetext{
${ }^{116}$ Michael Herr, OBSERVER (London, Jan. 15, 1989)

117 See POW Convention, art 7.

118 See id.

${ }^{119}$ See United States v. Hamdan, Ruling on Defense Motion for Article 5 Status Determination (Allred, J.), (Dec. 17, 2007) at 4.

${ }^{120}$ See supra text accompanying notes 17 and 18.
} 
the view that decisions which might have the gravest consequences should not be left to a single person." 121

Judge Allred, nevertheless, rules that he, sitting alone, will serve as an Article 5 tribunal. The jurisdictional hearing that he will conduct, the ruling says, “will also determine [Hamdan’s] status for the purposes of Article 5.”122

In holding that his sole decision will serve "for purposes of Article 5"-while simultaneously acknowledging the composition requirement of Article 5-Judge Allred appears to rely on a theory of waiver. In the sentence preceding the one stating that Judge Allred will sit as an Article-5 tribunal, the ruling states that, the "parties have conceded that this Commission is a competent tribunal within the meaning of Article 5."123 At oral argument, Joe McMillan, civilian counsel for Hamdan, did indeed state that Judge Allred could, sitting alone, serve as an Article 5 tribunal. The colloquy was as follows. ${ }^{124}$

Judge Allred: "How would an Article 5 tribunal proceeding differ from what we would conduct this afternoon?”125 Mr. McMillan responded that, if sitting as a competent tribunal, the commission should consider all six bases for lawful combatant status specified in the POW Convention and not only the three of those bases included in the MCA. ${ }^{126}$ Judge Allred: “I take it that you concede that this Court is a competent tribunal.”127 Lacking a definite response to that

\footnotetext{
${ }^{121}$ United States v. Hamdan, Ruling on Defense Motion for Article 5 Status Determination (Allred, J.), (Dec. 17, 2007) at 2 (quoting the Commentary to the POW Convention).

${ }^{122} I d$.

${ }^{123}$ See United States v. Hamdan, Ruling on Defense Motion for Article 5 Status Determination (Allred, J.), (Dec. 17, 2007) at 4 (emphasis added).

${ }^{124}$ Contemporaneous notes of author taken at Military Commission Hearing on the Defense Motion for an Article 5 Tribunal, United States v. Hamdan, (Dec. 5-6, 2007 Guantanamo Bay, Cuba). TO BE REPLACED WITH QUOTES FROM TRANSCRIPT.

${ }^{125}$ Supra note 89.

${ }^{126} I d$.

Explain re the $6 \mathrm{v}$. the 3.

${ }^{127} I d$.
} 
question, Judge Allred asked (after a brief digression), "Do you agree that this commission can be a competent tribunal?”,128 Mr. McMillan: "Yes.”129

Of course, Judge Allred knows that he, sitting alone, cannot constitute “a competent tribunal within the meaning of Article 5.” Indeed, he has explained why an Article 5 tribunal must be composed of more than one person. But, apparently treating Hamdan’s “concession”at oral argument—as a waiver of the Article 5 composition requirement, Judge Allred holds that he will sit as an Article 5 tribunal.

Hamdan cannot “concede” a part of his Article-5 right to a combatant status determination by a competent tribunal composed of more than one person. Article 7 of the POW Convention, entitled “Non-Renunciation of Rights,” states: "Prisoners of war may in no circumstances renounce in part or in entirety the rights secured to them by the present convention.”130 A purported waiver of POW rights is, thus, a legal nullity. It provides no justification for abrogation of the right purportedly waived.

The POW Convention bars any waiver of POW rights because those rights would be nearly meaningless if they were waivable, given the ease with which duress can be applied to detainees. $^{131}$ The bar to the waiver of POW rights is crucial in safeguarding those rights. To give legal effect to their purported waiver creates a dangerous precedent, discarding the shield that protects all the other POW rights.

Judge Allred was bound by the CMCR's Khadr opinion when he issued the December 17 ruling in Hamdan. The CMCR's Khadr opinion constrained Judge Allred's ability to interpret the MCA in accordance with the law of war and the Charming Betsy canon. The CMCR opinion

\footnotetext{
${ }^{128} \mathrm{Id}$.

${ }^{129} \mathrm{Id}$.

${ }^{130}$ POW Convention, supra note 13, art. 7 (emphasis added).

${ }^{131}$ See, COMMENTARY TO THE POW CONVENTION, supra note 13 at 89.
} 
required Judge Allred to exercise initial jurisdiction to determine the commission's jurisdiction. Nevertheless, Judge Allred had three options that would have allowed him to rule consistently with the CMCR while also protecting and remaining faithful to the law of war.

First, in exercising initial jurisdiction to adjudicate Hamdan’s motion challenging personal jurisdiction—as the CMCR opinion required—Judge Allred might have held that the military commission lacked jurisdiction to conduct further proceedings because, never having had a status determination by a competent tribunal, Hamdan was a presumptively lawful combatant—and would remain so until that presumptive status was rebutted by an Article 5 competent tribunal composed of more than one person. Second, Judge Allred, if he found it impossible to comply the CMCR decision while also complying with the MCA and the law of war, might have said so—-holding in accordance with the CMCR, while also elucidating the problems in so holding.

Or third, Judge Allred might have ruled (on his own motion, since the parties did not raise this point) that the military commission lacked personal jurisdiction over Hamdan because the charges against Hamdan were jurisdictionally defective when sworn. The MCA states that, “military commissions under this chapter shall not have jurisdiction over lawful enemy combatants." ${ }^{\text {32 }}$ Until a competent tribunal determines otherwise, a detained combatant is legally presumed to be a lawful enemy combatant. ${ }^{133}$ Rule for Military Commission (RMC) 202(c) states: "The jurisdiction of a military commission over an individual attaches upon the swearing of charges.”134 Since the MCA prohibits military commission jurisdiction over lawful combatants, and military commission jurisdiction attaches upon the swearing of charges, a detainee’s presumptive lawful combatant status would have to be rebutted—by a competent

\footnotetext{
${ }^{132}$ Id. § 948d(b).

${ }^{133}$ See supra 14.

${ }^{134}$ RMC 202(c).
} 
tribunal's determination of unlawful combatant status—before military commission charges could lawfully be sworn against that person and military commission jurisdiction, consequently, attach.

RMC 905(b) governs motions concerning defective charges. In this section of the RMC, the swearing of charges is referred to as the "preferral" of charges, a synonymous term in military practice. $^{135}$

RMC 905. Motions generally

(b) Pre-trial motions. .... The following must be raised before a plea is entered:

(1) Defenses or objections based on defects (other than jurisdictional defects) in the preferral, forwarding, investigation, or referral of charges. ...

Discussion

Such nonjurisdictional defects include unsworn charges and inadequate pretrial advice.

(2) Defenses or objections based on defects in the charges and specifications (other than any failure to show jurisdiction or to charge an offense, which objections shall be resolved by the military judge at any time during the pendency of the proceedings). ${ }^{136}$

As reflected in RMC 905(b), a defect in preferred charges may be jurisdictional or nonjurisdictional. As an example of a non-jurisdictional defect in preferred charges, the RMC offers, "unsworn charges." (The RMC offers no examples of a defect in preferred charges that would be jurisdictional.) Preferral of charges against a person legally presumed to be a lawful enemy combatant would be a prime example of a jurisdictionally defective preferral under a statute that plainly states: "Military commissions under this chapter shall not have jurisdiction over lawful enemy combatants."137

No independent action by the convening authority or the military commission judge can cure that jurisdictional defect in the preferral. A detained enemy combatant remains a

\footnotetext{
${ }^{135}$ MCM 307

${ }^{136}$ RMC 905(b) (emphasis added) (internal references omitted).

${ }^{137} 10$ U.S.C. $§ 948 d(b)$.
} 
presumptively lawful combatant—over whom military commission jurisdiction may not attach under the MCA—unless and until the presumption of lawful combatant status is rebutted by a competent tribunal. In the absence of such a competent-tribunal determination, the accused is legally presumed to be a lawful combatant over whom, the MCA explicitly states, military commission jurisdiction may not attach.

The preferral of military commission charges against a presumptively lawful combatant is not some merely "technical" defect to be cured, nunc pro tunc, later on. The attachment of jurisdiction begins the process of prosecution. The accused is informed that he will be tried by military commission for specified crimes. ${ }^{138}$ A defense lawyer is assigned; ${ }^{139}$ and discovery begins. ${ }^{140}$ Charges are amended and referred ${ }^{141}$ —as capital or non-capital cases ${ }^{142}$-by the convening authority. Pretrial proceedings commence. ${ }^{143}$ With each step, the power of the military commission is exercised; the prosecutor, the defense counsel, and the convening authority take actions with potentially profound consequences for the detainee.

Among the consequences of the attachment of military commission jurisdiction is the exclusion of the detainee from the Administrative Review Board (ARB) process. The ARB is "an administrative review process to assess annually the need to continue to detain each enemy combatant." ${ }^{144}$ ARB review entails the possibility of release, repatriation, or amelioration of the conditions of custody for detainees deemed "no longer a threat to the United States and its

\footnotetext{
138 See 10 U.S.C. § 948q(b); R.M.C. 308..

139 See 10 U.S.C. $\S 948 \mathrm{k}(3)$.

140 See R.M.C. 701.

141 See R.M.C. 407.

${ }^{142}$ See R.M.C. 601(e).

143 R.M.C. 707.

${ }^{144}$ Paul Wolfowitz, Order for Administrative Review Procedures for Enemy Combatants in the Control of the Department of Defense at Guantanamo Bay Naval Base, Cuba, at 1 (May 11, 2004) available at http://www.defenselink.mil/news/May2004/d20040518gtmoreview.pdf.
} 
allies." ${ }^{145}$ Upon attachment of military commission jurisdiction, the accused are "excepted from the $[\mathrm{ARB}]$ procedures ... until the disposition of any charges against them or the service of any sentence imposed by a military commission." ${ }^{146}$ The preferral of military commission charges is, thus, in several respects, an extremely serious matter, the deleterious consequences of which commence, for the detainee, immediately upon the preferral (swearing) of those charges.

The charges preferred against Mr. Hamdan—a presumptively lawful combatant—were jurisdictionally defective. He has, nevertheless, by the date of this writing, been convicted —on five out of ten counts chargerd—and sentenced. Pursuant to carefully and well constructed panel instructions, and with credit for time served thoughtfully ensured by Judge Allred, the sentence amounted to five months of prison time remaining at the time the sentence was announced.

Legal developments on personal jurisdiction under the MCA clearly have not come to a resting place. Judge Brownback’s June 4, 2007 ruling dismissing the charges against Omar Khadr correctly applied the MCA and the law of war. It did not, though, provide a full articulation of the reasons or the legal support for the outcome. The subsequent decisions on personal jurisdiction under the MCA, issued by the CMCR and by Judge Allred, have been, in important way s, inconsistent with the law of war and with a proper interpretation of the MCA. Those precedents, if left uncorrected, will do substantial damage to POW protections.

\section{The Current Posture: Preferring Defects}

Every case brought, to date, under the MCA has rested on a jurisdictionally defective preferral. Each charge was jurisdictionally defective when preferred, having been preferred against a person legally presumed to be a lawful enemy combatant, even while the MCA explicitly prohibits military commission jurisdiction over a lawful enemy combatant.

\footnotetext{
${ }^{145} \mathrm{Id}$.

${ }^{146}$ Id. at 4.
} 
The Guantanamo military commission proceedings, to date, have thus been ultra vires; they have exceeded the scope of the commissions' lawful authority. The proceedings to date have lacked legislative authorization. They are not the proceedings that Congress authorized in the Military Commissions Act of 2006.

\section{Conclusion}

When the MCA is read as a whole and in conjunction with the international law of war, its jurisdictional structure is revealed to be both logically consistent and consistent with the law of war.

The law of war has developed over centuries — and, particularly, during the past few decades - with the support, and often at the initiative, of the United States. The safeguards of Articles 5 and 45 that are eroded by the CMCR's 2007 Khadr opinion and further eroded in the December 17 military-commission ruling in Hamdan were developed in response to the mistreatment of American service members in Korea and Vietnam, and were designed to protect POW rights in the future.

Recalling the brutalities that led to the negotiation of Protocol I, George Aldrich, head of the US delegation in those negotiations, commented in 2002: "When [Article 45(2)] was negotiated, the United States government was painfully aware of the experiences in Korea and Vietnam, where many American military personnel were mistreated by their captors and denied POW status by mere allegations that they were all criminals. Time evidently dulls memory."

The law of war is a long-term proposition. The purposes motivating US support for Article 45(2) are as significant now as they were in the aftermath of the Korean and Vietnam wars. As Michael Herr has cogently observed, “All the wrong people remember Vietnam. I

\footnotetext{
${ }^{147}$ Aldrich, supra note 25, at 898 [internal citations omitted].
} 
think all the people who remember it should forget it, and all the people who forgot it should remember it." ${ }^{\prime 48}$

This should be an easy call. The MCA provisions on personal jurisdiction provide for compliance with the law of war and, indeed, demand it. What is required to achieve a coherent interpretation of the MCA's personal jurisdiction framework, to comply with that framework, and to protect POW rights and fulfill US obligations under the law of war is simply to conduct a handful of combatant status determinations before competent tribunals. The cost of noncompliance is very high; and, the cost of compliance is miniscule.

${ }^{148}$ Michael Herr, Observer ( Jan. 15, 1989). 


\section{APPENDIX A}

UNITED STATES OF AMERICA

$\mathrm{V}$.

SALIM AHMED HAMDAN

RULING ON DEFENSE MOTION FOR

ARTICLE 5 STATUS DETERMINATION

17 December 2007

The Defense has moved this Commission to make a status determination, as required by Article 5 of the Geneva Conventions Relative to the Treatment of Prisoners of War (hereinafter GPW), or that the charges against him be dismissed for lack of personal jurisdiction. The Defense argues that the accused has claimed to be entitled to Prisoner of War Status, that as a result he is not subject to trial by Military Commission absent a determination of his status, and that the burden of proof in any such determination is upon the Government, beyond a reasonable doubt. The Government opposes the motion, arguing alternatively that the Accused is not entitled to an Article 5 status determination because GPW is implemented by the Military Commissions Act and does not apply; that if it does apply, the accused's October 2004 CSRT hearing satisfies it; and finally, that this Commission can hear the evidence and perform the Article 5 determination. The Government disputes the Defense contention that it must prove jurisdiction "'beyond a reasonable doubt", and argues that the correct standard is "preponderance of the evidence."

\section{BURDEN OF PROOF}

Having read the written briefs of both parties, and carefully reviewed the authorities cited in each, the Commission concludes that the burden upon the Government in an initial showing of jurisdiction is preponderance of the evidence. RMC 905(c)(I); United States v. Khadr, (CMCR 07-001, 24, 25). At trial, if the accused raises a affirmative defense, such as the defense of lawful combatancy, the Government will be required to disprove that defense beyond a reasonable doubt. RMC 916(b). United States v. Khadr, at 7. Thus, the burden of demonstrating that the accused is subject to the jurisdiction of this Commission is on the Government, by a preponderance of the evidence.

\section{ENTITLEMENT TO AN ARTICLE 5 STATUS DETERMINATION}

Article 5 of the Third Geneva Convention, by which the United States is bound, provides: "'The Present Convention shall apply to the persons referred to in Article 4 from the time they fall into the power of the enemy and until their final release and repatriation. Should any doubt arise as to whether persons, having committed a belligerent act and having fallen into the hands of the enemy, belongs to any of the categories enumerated in Article 4 , such persons shall enjoy the protection of the present Convention until such time as their 
status has been determined by a competent tribunal."

Referring to Article 5, Howard S. Levie writes "The present article was an attempt to eliminate, or at least to reduce, the number of instances in which military personnel in the field make an arbitrary decision that a captured individual is an illegal combatant and impose summary justice .... [ [it] assures the accused not only of a determination by a competent tribunal, but of a further judicial tribunal-but only if the detaining power proposes to try him for an offense arising out of the hostilities." Howard S. Levie, The Code of International Armed Conflict, Vol. I, Oceana Publications, (Rome, London, New York: 1986) at 305-6 (emphasis added).

Discussing the same provision, Jean S. Pictet of the International Committee of the Red Cross described the deliberations in these terms "At Geneva in 1949, it was first proposed that for the sake of precision the term "responsible authority" should be replaced by "military tribunal". This amendment was based on the view that decisions which might have the gravest consequences should not be left to a single person, who might often be of subordinate rank. The matter should be taken to a court, as persons taking part in the fight without the right to do so are liable to be prosecuted for murder or attempted murder, and might even be sentenced to capital punishment ..." Jean S. Pictet, Commentary Relative to the Treatment o/Prisoners o/War, III. International Committee of the Red Cross, Geneva 1960 at 77 (emphasis added).

When the drafters sought to clarify when such a determination should be made, there was disagreement. "In view of the great differences in national judicial procedures, it was not thought possible to establish a firm rule that this question [an accused's status] must be decided before the trial for the offense, but it should be so decided if at all possible, because on it depends the whole array of procedural protections accorded to Prisoners of War, by the Third Convention, and the issue may go to the jurisdiction of the tribunal." Yves Sandoz et. aI, eds. Commentary on the Additional Protocols o.f8 June 1977 to the Geneva Conventions of12 August 1949, International Committee of the Red Cross (Geneva 1987) at 556.

These authorities suggest that the United States is bound not only to perform an initial status determination, such as that provided for under Army Regulation 190-8, but a second, judicial, determination when it proposes to try an detainee for his participation in hostilities. The Government argues that "he has done nothing to trigger" Article 5, but the Commission finds that his claim of entitlement to POW status, made by his counsel before this tribunal, is sufficient to do so. It further finds that because the United States, as Detaining Power, proposes to try the accused for his participation in hostilities, the Geneva Conventions clearly contemplated a judicial determination of his status before any such proceeding.

Congress was clearly aware of these treaty obligations under Article 5 when it debated and enacted the Military Commissions Act. Congress clearly intended that the Combatant Status Review Tribunal (CSRT) would satisfy the requirements of Article 5. Senator Lindsey Graham characterized CSRT's as "Article 5 tribunals on steroids". 151 Congo Rec. S12,754 (daily ed. Nov 14, 2005), and the Government concedes that there was a "bipartisan consensus" that the CSRT would satisfy the requirements of Article 5. In support of this concession, the Government invites the Commission's attention to this colloquy:

2

"SEN Graham: Okay, now, we have a CSRT procedure that Senator Levin and myself 
and others worked on that deals with determining enemy combatant status. This is a non-criminal procedure that is designed to comply with ... Article 5 of the Geneva Convention, a competent tribunal. Does everyone on the panel believe that the CSRT procedures ... as constituted, meet [] the test of what the Geneva Convention had in mind as determining status?

GEN Romig: Yes, Sir.

GEN. Black: Yes, Sir.

SEN Graham: ... Not only does it meet the test, it's gotten better over time... Not only did we put in place the CSRT ... procedure that would comply with Geneva Convention status determination competent tribunal standards, we also allowed civilian review of those decisions for the first time...."' Hearings Before the Senate Committee on Armed Services, Military Commissions in Light of the Supreme Court Decision in Hamdan v. Rumsfeld, S. Hrg. 1090-881, at 62-63 (July 13, 2006). Elsewhere in the Congressional Record, Senator Kyl opined that the CSRT process would satisfy Article 5' s requirement of a status determination before a competent tribunal, and give even more protections than Article 5 requires. Id., at S10,268.

It is clear to the Commission that Congress intended that the accused have an Article 5 status determination in any case in which his status was in doubt, and that it intended the CSRT process to make such a determination.

DID THE ACCUSED'S OCTOBER 2004 CSRT SATISFY ARTICLE 5?

The CSRT held in this case was governed by a Deputy Secretary of Defense Memorandum dated 7 July 2004 and a Secretary of the Navy Order dated 29 July 2004. The Report of the CSRT, dated 8 October 2004, concludes in pertinent part that: "2. (U) On 3 October 2004, the Tribunal determined, by a preponderance of the evidence, that [the accused] is properly designated as an enemy combatant as defined in [DEPSECDEF Memo of7 July 2004].

3. (IJ) In particular, the Tribunal finds that this detainee is a member of, or affiliated with, al-Qaida forces, as more fully discussed in the enclosures."

It is clear from a reading of the balance of the CSRT Report that the panel members found Hamdan to be an "enemy combatant" because of his membership in al-Qaeda, and because he had been employed by Osama bin-Ladin as a bodyguard and driver. The CSRT did not address his entitlement to Prisoner of War Status, cite or discuss the Geneva Conventions or A11icle 5, or address the lawfulness of the accused's participation in hostilities. Indeed, it was not tasked to do so, the DEPSECDEF and SECNAV Memoranda having ordered the CSRT to make a different determination: whether the accused was an "enemy combatant", as defined in those references, for purposes of continuing his detention. As a consequence, this Commission cannot accept the 2004 CSRT determination that the accused is properly detained as an "enemy combatant" in satisfaction of the required determination regarding his entitlement to Prisoner of War Status. Even if the Commission were to agree with the Government that the 2004 CSRT process satisfied Article 5, it is clear from the Commentaries on the Geneva Conventions that a second status determination must be made by a judicial officer for detainees the Detaining Power proposes to punish.

Both parties have conceded that this Commission is a competent tribunal within the meaning of Article 5. The hearing the Commission will undertake to determine whether the accused is an alien unlawful enemy combatant, and therefore subject to the Commission's jurisdiction will also determine his status for the purposes of Article 5. This procedure is fully consistent with the intent of Congress., the Law of Armed Conflict., and the decision of the Court of rv1ilitary Commission Review in United States v. Khadr.

The Commission notes the terms of MCA $§ 948 b(\mathrm{~g})$., which provide "No alien unlawful 
enemy combatant subject to trial by military commission under this chapter may invoke the Geneva Conventions as a source of rights." Because the accused has not yet been determined to be an alien unlawful enemy combatant by any tribunal., this section does not apply to defeat his right to rely on the Geneva Conventions for the purposes of determining his status.

The Defense Motion for an Article 5 Status Determination is GRANTED.

So Ordered this 17th day of December., 2007.

Keith Allred

Captain., JAGC., US Navy

Military Judge 